Prepared in cooperation with the Yukon Delta National Wildlife Refuge

\title{
Abundance, Timing of Migration, and Egg-to-Smolt Survival of Juvenile Chum Salmon, Kwethluk River, Alaska, 2007 and 2008
}

Open-File Report 2010-1028 



\section{Abundance, Timing of Migration, and Egg-to-Smolt Survival of Juvenile Chum Salmon, Kwethluk River, Alaska, 2007 and 2008}

By Sean E. Burril, Christian E. Zimmerman, and James E. Finn, U.S. Geological Survey, and Daniel Gillikin, U.S. Fish and Wildlife Service

Prepared in cooperation with the Yukon Delta National Wildlife Refuge

Open-File Report 2010-1028

Prepared for Arctic-Yukon-Kuskowim Sustainable Salmon Initiative

Project 619

August 2009 


\section{U.S. Department of the Interior \\ KEN SALAZAR, Secretary}

\section{U.S. Geological Survey \\ Marcia K. McNutt, Director}

U.S. Geological Survey, Reston, Virginia: 2010

For more information on the USGS-the Federal source for science about the Earth, its natural and living resources, natural hazards, and the environment, visit $h$ ttp://uww.usgs.gov or call 1-888-ASK-USGS.

For an overview of USGS information products, including maps, imagery, and publications, visit http://uww.usgs.gov/pubprod

To order this and other USGS information products, visit http://store.usgs.gov

Suggested citation:

Burrill, S.E., Zimmerman, C.E., Finn, J.E., and Gillikin, Daniel, 2010, Abundance, timing of migration, and egg-to-smolt survival of juvenile chum salmon, Kwethluk River, Alaska, 2007 and 2008: U.S. Geological Survey Open-File Report 2010-1028, $28 \mathrm{p}$.

Any use of trade, product, or firm names is for descriptive purposes only and does not imply endorsement by the U.S. Government.

Although this report is in the public domain, permission must be secured from the individual copyright owners to reproduce any copyrighted material contained within this report. 


\section{Contents}

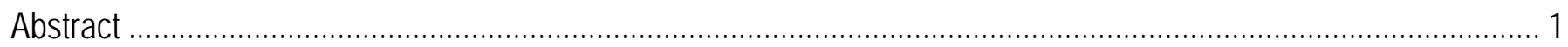

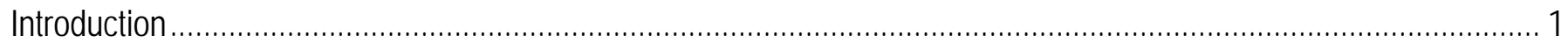

Description of Study Area

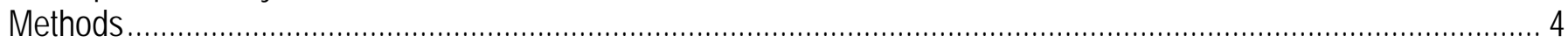

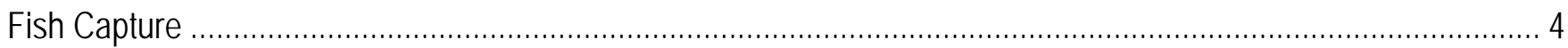

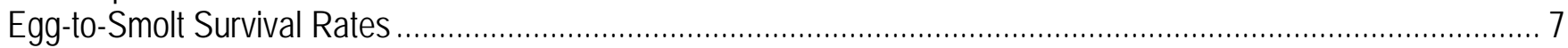

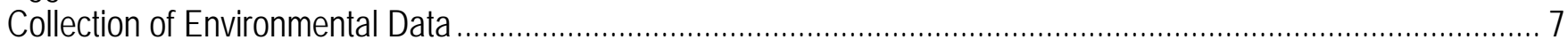

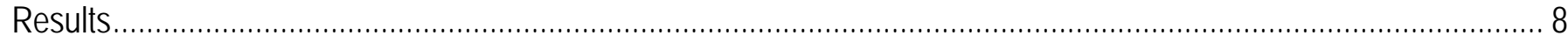

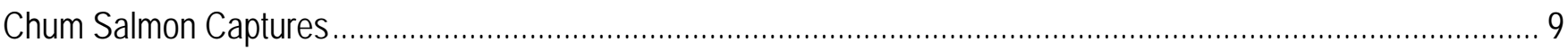

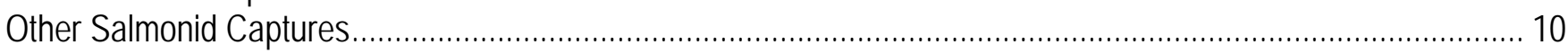

Estimates of Abundance and Survival of Chum Salmon ....................................................................... 15

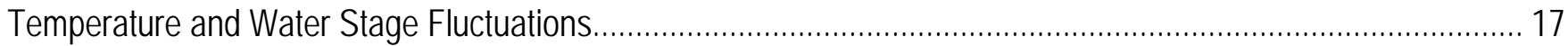

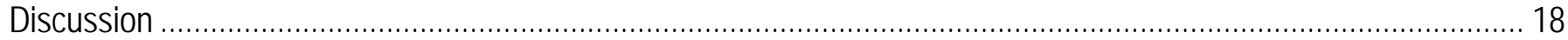

Summary

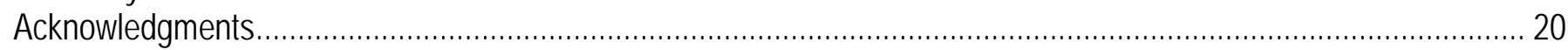

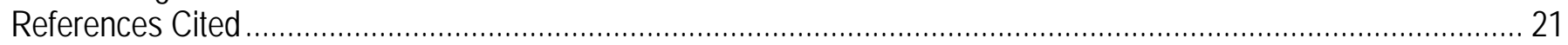

Appendix A. Mark-recapture data for fish traps used in the Kwethluk River, Alaska, 2007 and 2008 _........................ 24

Appendix B. Daily catches of juvenile chum salmon along with readings for water stage, maximum water temperature, and minimum and maximum air temperature, Kwethluk River, 2007 and 2008 ................................. 26

\section{Figures}

Figure 1. Location of study site (circle), Kwethluk River, Alaska ........................................................................ 3

Figure 2. Schematic side view of an inclined plane trap (not to scale) ............................................................... 4

Figure 3. Floating inclined plane trap as used on the Kwethluk River, Alaska ........................................................ 5

Figure 4. Inclined plane trap with ice-breaker bow attached, Kwethluk River, Alaska............................................. 6

Figure 5. Inclined plane traps attached to cable spanning the Kwethluk River, Alaska............................................. 6

Figure 6. Daily catch of juvenile chum salmon and maximum daily water stage for the Kwethluk River, Alaska

Figure 7. Total catch of juvenile chum salmon in 2007 (solid circles) and 2008 (open circles), Kwethluk River, Alaska.

Figure 8. Daily catch of age-0 juvenile salmon on the Kwethluk River, Alaska .

Figure 9. Total catch of Chinook and coho salmon (A) and sockeye and pink salmon (B) in the Kwethluk River, Alaska, 2007

Figure 10. Total catch of juvenile Chinook and coho salmon (A) and sockeye and pink salmon (B) in the Kwethluk River, Alaska, 2008

Figure 11. Daily catch of age 1+ juvenile salmon in the Kwethluk River, Alaska.

Figure 12. Daily water stage and water temperature for the Kwethluk River, Alaska, 2007-08. 


\section{Tables}

Table 1. Total catch for salmon species by age and total catch for all other fish species caught in inclined plane traps on the Kwethluk River, Alaska, 2007 and 2008.

Table 2. Mark-recapture events, numbers of juvenile chum salmon marked and recaptured, and overall efficiency of inclined plane traps on the Kwethluk River, Alaska, 2007 and 2008.

Table 3. Egg-to-smolt survival of chum salmon determined in this and other studies.

\section{List of Abbreviations}

$\begin{array}{ll}\text { AYK } & \text { Arctic Yukon Kuskokwim } \\ \text { CI } & \text { Confidence Interval } \\ \text { NRC } & \text { National Research Council } \\ \text { OVK } & \text { Organized Village of Kwethluk } \\ \text { PED } & \text { Potential Egg Deposition } \\ \text { SD } & \text { Standard Deviation } \\ \text { SE } & \text { Standard Error } \\ \text { USFWS } & \text { U.S. Fish and Wildlife Service } \\ \text { USGS } & \text { U.S. Geological Survey }\end{array}$

\section{Conversion Factors}

SI to Inch/Pound

\begin{tabular}{lcl}
\hline & Multiply & \\
\hline & Length & To obtain \\
\hline millimeter (mm) & 0.03937 & inch (in.) \\
centimeter (cm) & 2.54 & inch (in.) \\
meter (m) & 3.281 & foot (ft) \\
kilometer (km) & 0.6214 & mile (mi) \\
kilometer (km) & 0.5400 & mile, nautical (nmi) \\
\hline & Area & \\
\hline square kilometer $\left(\mathrm{km}^{2}\right)$ & 247.1 & acre \\
\hline & Volume & \\
\hline liter (L) & 33.82 & ounce, fluid (fl. oz) \\
liter (L) & 2.113 & pint (pt) \\
liter (L) & 1.057 & quart (qt) \\
liter (L) & 0.2642 & gallon (gal) \\
\hline & Mass & \\
\hline gram (g) & 0.03527 & ounce, avoirdupois (oz) \\
\hline
\end{tabular}

Temperature in degrees Celsius $\left({ }^{\circ} \mathrm{C}\right)$ may be converted to degrees Fahrenheit $\left({ }^{\circ} \mathrm{F}\right)$ as follows: ${ }^{\circ} \mathrm{F}=\left(1.8 \times{ }^{\circ} \mathrm{C}\right)+32$.

Temperature in degrees Fahrenheit $\left({ }^{\circ} \mathrm{F}\right)$ may be converted to degrees Celsius $\left({ }^{\circ} \mathrm{C}\right)$ as follows: ${ }^{\circ} \mathrm{C}=\left({ }^{\circ} \mathrm{F}-32\right) / 1.8$. 


\title{
Abundance, Timing of Migration, and Egg-to-Smolt Survival of Juvenile Chum Salmon, Kwethluk River, Alaska, 2007 and 2008
}

By Sean E. Burril1, Christian E. Zimmerman¹, and James E. Finn¹, U.S. Geological Survey, and Daniel Gillikin², U.S. Fish and Wildlife Service

\begin{abstract}
To better understand and partition mortality among life stages of chum salmon (Oncorhynchus keta), we used inclined-plane traps to monitor the migration of juveniles in the Kwethluk River, Alaska in 2007 and 2008. The migration of juvenile chum salmon peaked in mid-May and catch rates were greatest when water levels were rising. Movement of chum salmon was diurnal with highest catch rates occurring during the hours of low light (that is, 22:00 to 10:00). Trap efficiency ranged from 0.37 to 4.04 percent (overall efficiency $=1.94$ percent). Total abundance of juvenile chum salmon was estimated to be 2.0 million fish in 2007 and 2.9 million fish in 2008. On the basis of the estimate of chum salmon females passing the Kwethluk River weir and age-specific fecundity, we estimated the potential egg deposition (PED) upstream of the weir and trapping site. Egg-to-smolt survival, calculated by dividing the estimate of juvenile chum salmon emigrating past the weir site by the estimate of PED, was 4.6 percent in 2007 and 5.2 percent in 2008. In addition to chum salmon, Chinook salmon (O. tshawytscha), coho salmon (O. kisutch), sockeye salmon (O. nerka), and pink salmon (O. gorbuscha), as well as ten other fish species, were captured in the traps. As with chum salmon, catch of these species increased during periods of increasing discharge and peaked during hours of low light. This study successfully determined the characteristics of juvenile salmon migrations and estimated egg-to-smolt survival for chum salmon. This is the first estimate of survival for any juvenile salmon in the Arctic-Yukon-Kuskokwim region of Alaska and demonstrates an approach that can help to partition mortality between freshwater and marine life stages, information critical to understanding the dynamics of salmon in this region.
\end{abstract}

\section{Introduction}

Declines in salmon returns to western Alaska rivers within the Arctic-Yukon-Kuskokwim (AYK) Region in the late 1990s and early 2000s resulted in restrictions to commercial and subsistence fisheries (National Research Council, 2005; Arctic-Yukon-Kuskokwim Sustainable Salmon Initiative, 2006). The reasons for these declines are unknown and difficult to identify because of a general lack of information concerning salmon populations and their habitats within this region. This severely hampers

\footnotetext{
${ }^{1}$ U.S. Geological Survey, 4210 University Drive, Anchorage, AK, USA

${ }^{2}$ U.S. Fish and Wildlife Service, Yukon Delta National Wildlife Refuge, PO Box 346, Bethel, AK, USA
} 
efforts by fishery managers and scientists to identify and develop appropriate management actions (National Research Council, 2005). Determining the relative importance of mortality in freshwater, estuarine, or marine habitats as drivers of recruitment variation would aid in assessing how management can respond to declining salmon returns. Traditionally, fishery managers have relied on escapement estimates to monitor anadromous salmonid population status and management effectiveness (Hilborn and others, 1999). Within the Kuskokwim River watershed, adult salmon returns are monitored at nine locations, and counts of adult salmon are used to construct stock-recruit relationships that are used to establish escapement goals (Clark and others, 2009; Linderman and Bergstrom, 2009). When based on adult returns only, these stock-recruit relationships integrate mortality across all life stages and habitats. Estimates of population abundances at earlier life stages would enable partitioning of survival among life-stages and aid in developing hypotheses for restoration and management actions (Moussalli and Hilborn, 1986; Mobrand and others, 1997; Beamish and Sweeting, 2009).

Within the Kuskokwim River, little work has been done to enhance understanding of the ecology of juvenile salmon. Quantification of juvenile salmon production at sites where adult salmon escapement is monitored would allow partitioning of mortality between the freshwater life stages (eggto-smolt) and marine life stages (smolt-to-adult) (Volkhardt and others, 2007). Fish traps commonly are used to capture and estimate the abundance (Tsumura and Hume, 1986; Orciari and others, 1994; Thedinga and others, 1994; Letcher and others, 2002), timing of migration (Wagner and others, 1963; Hartman and others, 1982), size at migration (Orciari and others, 1994), survival (Tsumura and Hume, 1986; Letcher and others, 2002), and behavior (Brown and Hartman, 1988; Roper and Scarnecchia, 1996) of downstream migrating anadromous salmonids. Coupled with estimates of adult salmon escapement, estimates of smolt abundance can be used to assess the capacities of freshwater habitats and effects of fishery and land-use management practices (Moussalli and Hilborn, 1986; Solazzi and others, 2000).

In the springs of 2007 and 2008, the U.S. Geological Survey, in cooperation with the Yukon Delta National Wildlife Refuge and the Arctic-Yukon-Kuskokwim Sustainable Salmon Initiative, estimated the population size, and calculated egg-to-smolt survival of migrating juvenile chum salmon (Oncorhynchus keta) on the Kwethluk River, Alaska. Although we focused our efforts on chum salmon, we also determined the timing of migration and relative abundance of Chinook salmon $(O$. tshawytscha), coho salmon (O. kisutch), sockeye salmon (O. nerka), and pink salmon (O. gorbuscha).

\section{Description of Study Area}

The Kwethluk River originates in the Kilbuk Mountains in southwestern Alaska and flows northwesterly for approximately $230 \mathrm{~km}$ before joining the Kuskokwim River $31 \mathrm{~km}$ upstream of Bethel (fig. 1). The Kwethluk watershed drains approximately 3,400 $\mathrm{km}^{2}$ and is characterized as a clearwater/tannin-stained run-off system. The Kwethluk River supports runs of chum, Chinook, coho, sockeye, and pink salmon. Other fish species occurring within the watershed include rainbow trout (O. mykiss), Dolly Varden (Salvelinus malma), Alaska blackfish (Dallia pectoralis), Arctic grayling (Thymallus arcticus), Northern pike (Esox lucius), whitefish (Coregonidae), burbot (Lota lota), ninespine stickleback (Pungitius pungitius), sculpin (Cottidae), and lamprey (Petromyzontidae). To monitor adult salmon returns to the Kwethluk River, the U.S. Fish and Wildlife Service, in cooperation with the Organized Village of Kwethluk, operates a resistance board weir at approximately river km 88 (60²9.38' N, $\left.161^{\circ} 05.54^{\prime} \mathrm{W}\right)$. Counts of salmon at the Kwethluk weir began in 2000, although a similar weir also was operated at this site in 1992 (Miller and others, 2009). Seven-year averages of salmon passing the Kwethluk weir are: 37,000 chum salmon; 14,000 Chinook salmon; 2,100 sockeye salmon; 1,900 even-year pink salmon; and 45,000 coho salmon (Miller and others, 2009). 


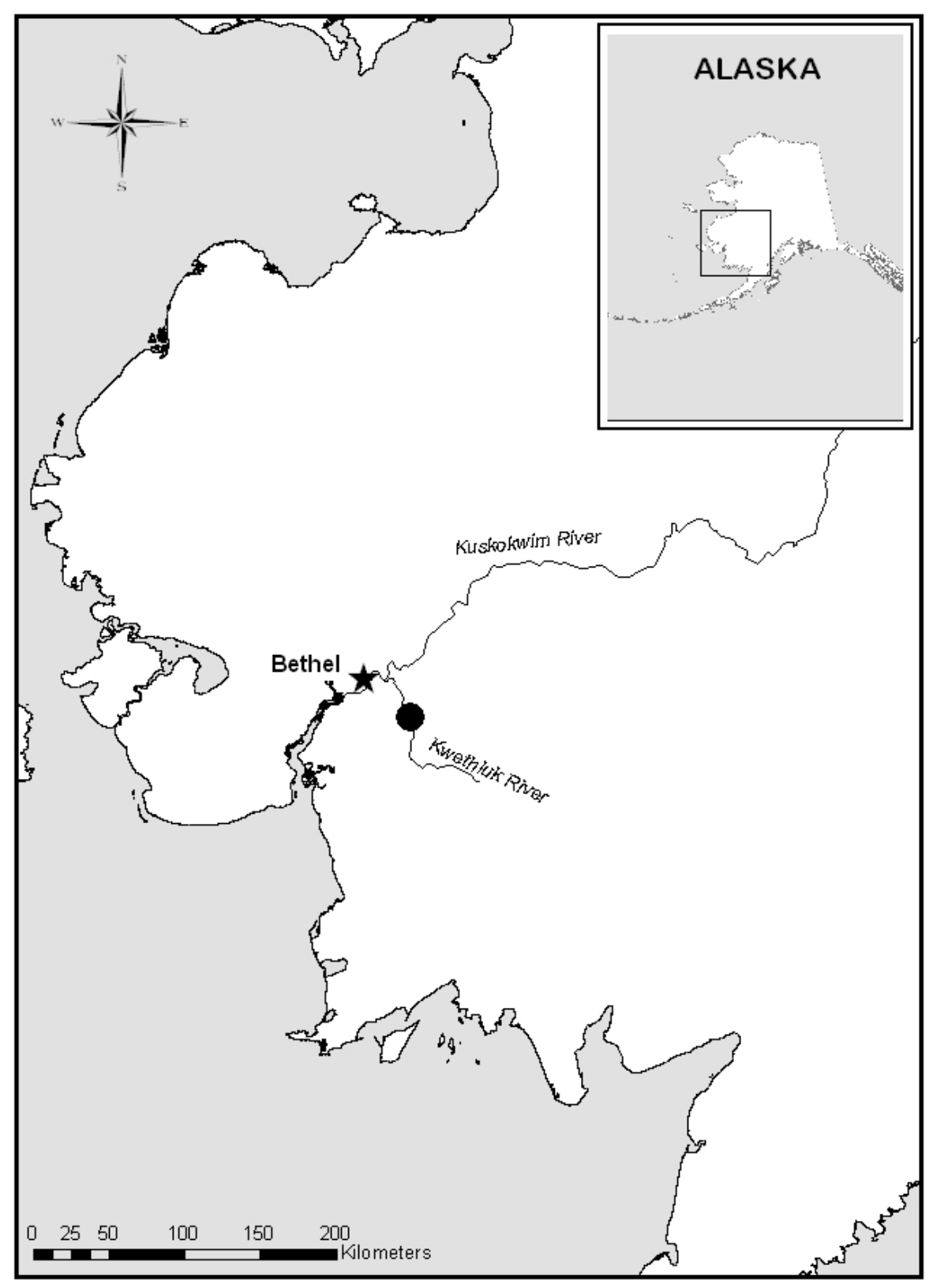

Figure 1. Location of study site (circle), Kwethluk River, Alaska. 


\section{Methods}

\section{Fish Capture}

Two floating inclined-plane traps, similar to those described by Todd (1994), were used to capture migrating salmon at the Kwethluk River weir site (fig. 1). The original design (Todd, 1994) was optimized for collecting sockeye salmon smolts. Our traps were modified for sampling smaller rivers and fish species. Specifically, the trap was scaled down for transport in small cargo aircraft, an additional winch was installed at the funnel/live-box junction so the entire trap could be lifted from the water, and perforations in the live-box and funnel were reduced to 9.5 and $3.5 \mathrm{~mm}$, to retain the smaller (compared to sockeye salmon smolts) juvenile chum salmon. These traps have a $1.2 \mathrm{~m} \times 1.2 \mathrm{~m}$ opening that narrows to a $0.9 \mathrm{~m} \times 0.2 \mathrm{~m}$ end that deposits fish into a live holding box (fig. 2).

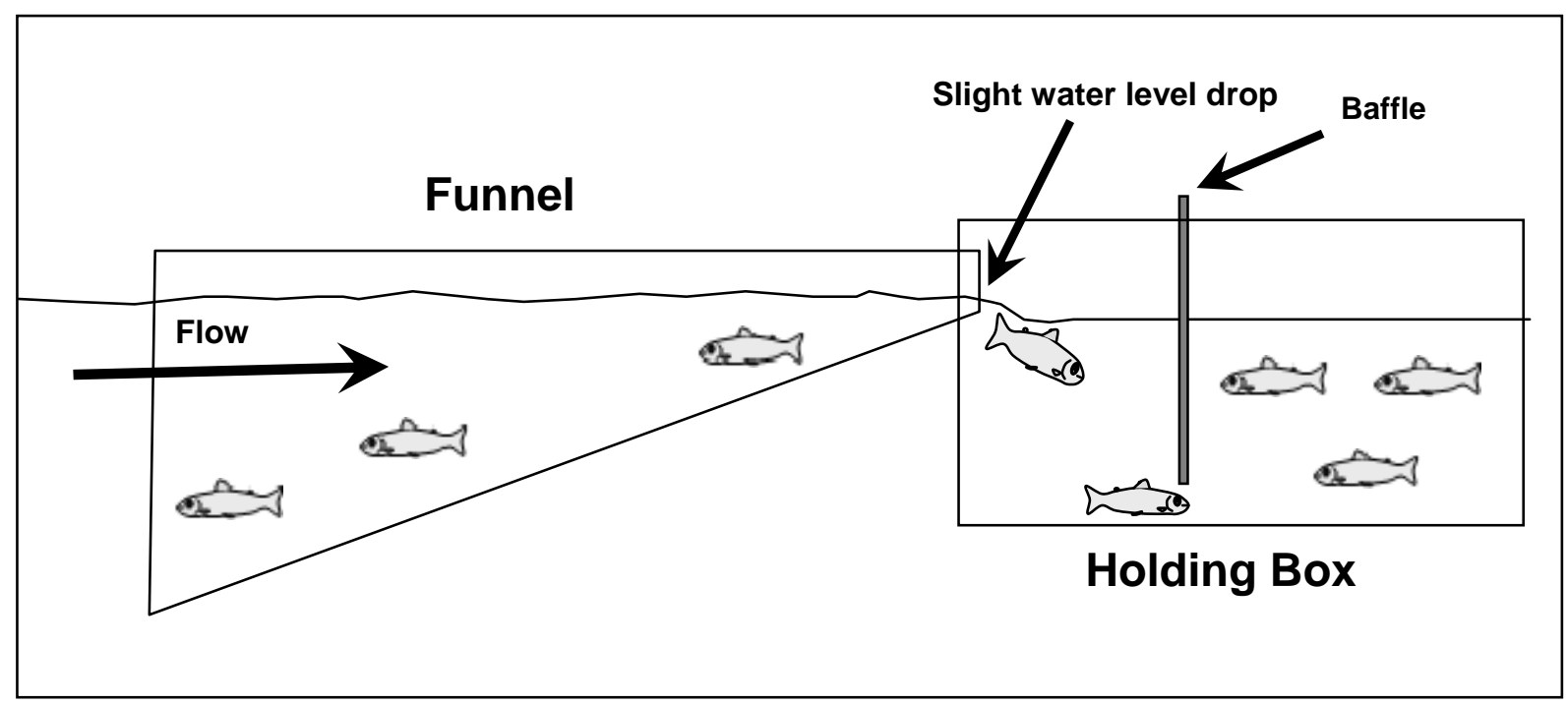

Figure 2. Schematic side view of an inclined plane trap (not to scale).

The plane and live-box are mounted atop two pontoon floats (fig. 3). Further, all anchors and lines were above water to avoid entanglement with floating debris and ice, and a floating deflector was attached at the upstream end to minimize floating ice and debris from entering the traps (fig. 4). The debris deflector was used only during periods when floating ice was present. 


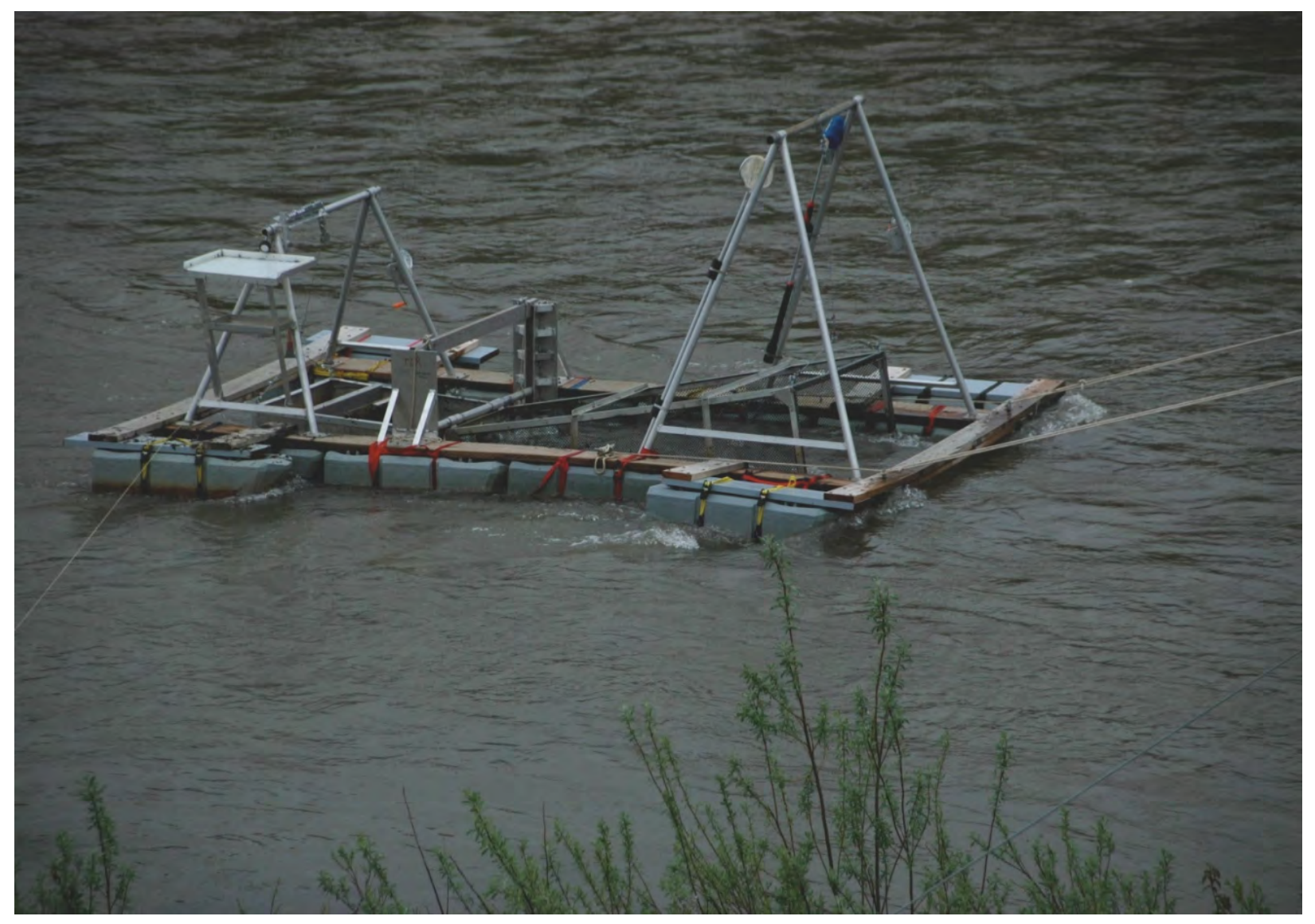

Figure 3. Floating inclined plane trap as used on the Kwethluk River, Alaska.

Traps were deployed in the spring of each year as soon as the river was free of ice cover at the trap site and were operated until the seaward migration of juvenile chum salmon subsided. Traps were tethered to a suspended cable that spanned the river width (fig. 5). Traps were checked every 4 hours in a 24-hour period except during periods of high flow or debris loads, when it was necessary to check the traps every 2 hours to avoid clogging of the plane and live box by debris. When traps were checked, all fish were counted and immediately released, except when fish were held for marking or measurement. Every third day, a subsample of up to 100 fish was measured and released. 


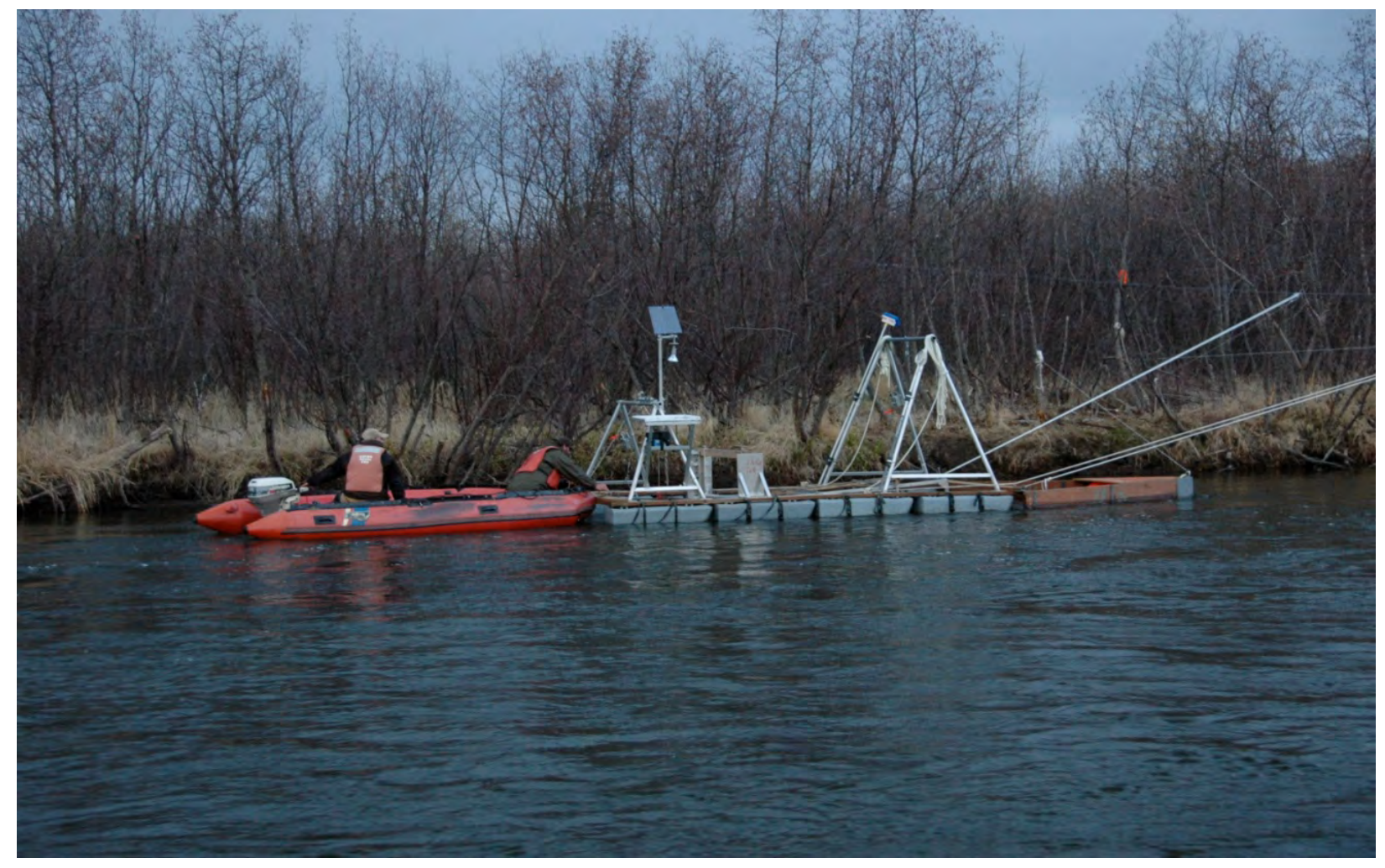

Figure 4. Inclined plane trap with ice-breaker bow attached, Kwethluk River, Alaska.

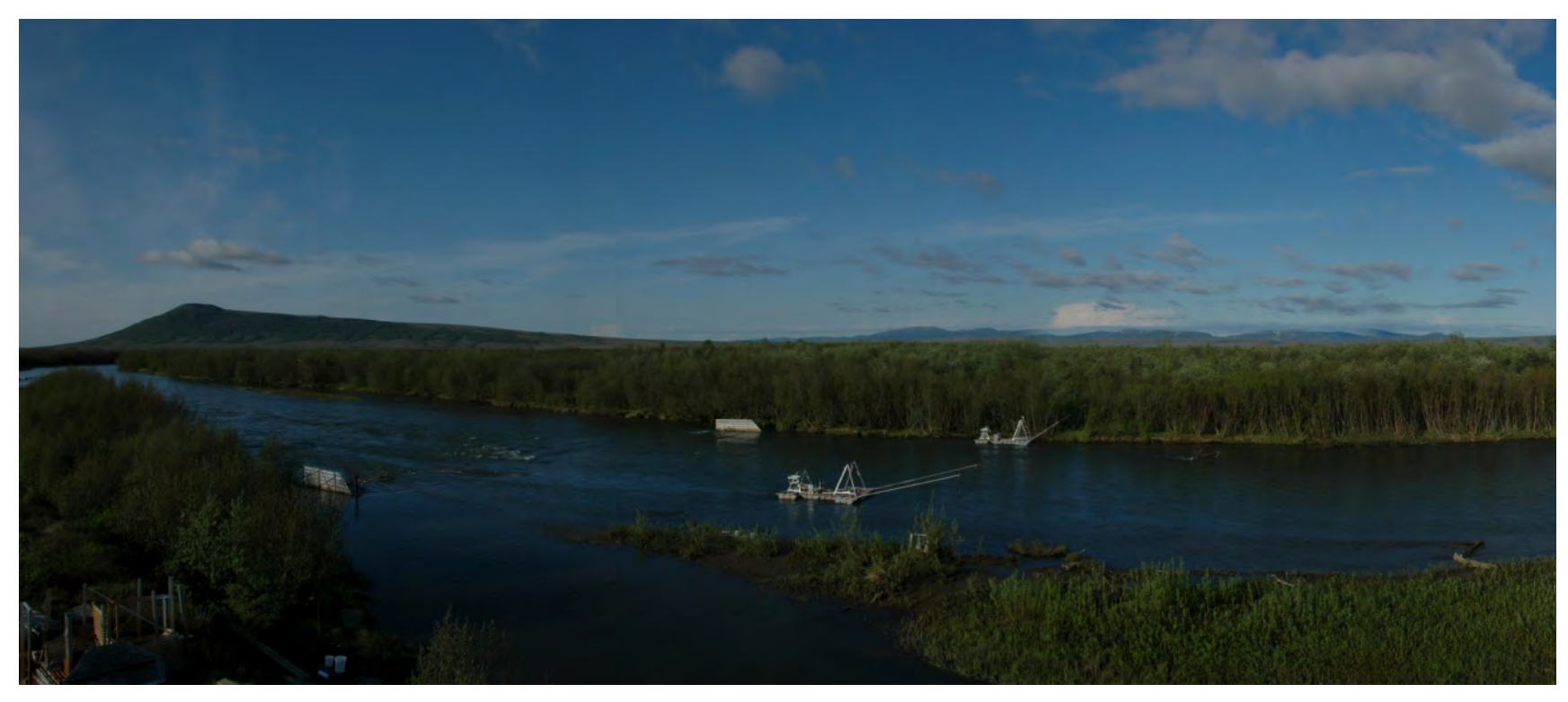

Figure 5. Inclined plane traps attached to cable spanning the Kwethluk River, Alaska. 
Numbers of chum salmon migrants passing the trap site were estimated using the mark-recapture methods and estimators developed by Carlson and others (1998), using a "One Trap” scenario consisting of two traps positioned on opposite banks. Trap efficiency was determined by releasing marked fish upstream of the trap site; trap efficiency was measured anytime traps were moved, when stream stage height changed by $10 \mathrm{~cm}$ or more, or once per week.

During mark-recapture events, fish were marked using a solution of Bismarck Brown Y dye (0.5 g dye/15 L of water). Fish were immersed in the marking solution for up to 2 hours and then held in flow-through tubs for a minimum of 2 hours prior to release. Following marking, 10-100 marked fish were held to monitor mortality and mark visibility during each marking event. The target number of marked smolts for any marking period was selected on the basis of estimated trap efficiency and the desired level of precision (Carlson and others, 1998). Marked fish were transported approximately $1 \mathrm{~km}$ upstream and released. For all marking events, fish were released as close to midnight as possible.

\section{Egg-to-Smolt Survival Rates}

Percent survival of juvenile chum salmon was determined using estimates of potential egg deposition (PED; the maximum number of eggs brought into the system by spawning females) and the estimated abundance of juvenile chum salmon passing the trap site. We estimated PED on the basis of the number of female chum salmon and their age distributions as determined at the weir (Miller and others, 2007, 2009) and literature values of age-specific fecundity (Gilk and others, 2005). After each field season, we used the estimated smolt number in conjunction with the previous (parental year) female escapement-fecundity estimate to calculate the survival. The survival estimate was calculated as:

$$
\text { \%Survival }=\frac{\text { estimated smolt abundance }}{\text { PED }} \cdot 100 .
$$

Variance was calculated using the delta method (Seber, 1982).

\section{Collection of Environmental Data}

Water stage and water and air temperature were monitored at the trap site. Upon arrival at the Kwethluk River field location, we installed a water-stage gage. Each day, water stage was recorded in the morning (08:00 hours) and again in the evening (20:00 hours). Water temperature was recorded using three temperature data loggers (set at 15-minute intervals) suspended from each trap, and one to a solid bank structure. The daily range in air temperature indicated by a min/max thermometer was recorded. 


\section{Results}

Inclined-plane traps were installed and operated from April 26 to May 31, 2007 and from April 29 to June 18, 2008. All five species of Pacific salmon and ten other species of fish were caught as they moved downstream past the trapping site (table 1). Juvenile chum salmon were the most abundant species in both years (table 1).

Table 1. Total catch of salmon species by age and total catch of all other fish species caught in inclined plane traps on the Kwethluk River, Alaska, 2007 and 2008.

\begin{tabular}{lrr}
\hline Species & $\mathbf{2 0 0 7}$ & $\mathbf{2 0 0 8}$ \\
\hline Chum salmon (Oncorhynchus keta) & 99,415 & 43,979 \\
Pink salmon (O. gorbuscha) & 3,005 & 963 \\
Total Chinook salmon (O. tshawytscha) & 14,221 & 2,135 \\
-- Age-0 Chinook salmon & 7,812 & 422 \\
--Age 1 Chinook salmon & 6,409 & 1,713 \\
Total Coho salmon (O. kisutch) & 3,872 & 2,274 \\
-- Age-0 Coho salmon & 478 & 226 \\
--Age 1 Coho salmon & 3,394 & 2,048 \\
Sockeye salmon (O. nerka) & 3,533 & 3,326 \\
-- Age-0 Sockeye salmon & 2,878 & 2,688 \\
--Age 1 Sockeye salmon & 655 & 638 \\
Sculpin (unidentified species) & 347 & 54 \\
Dolly Varden (Salvelinus malma) & 13 & 4 \\
Rainbow trout (O. mykiss) & 0 & 5 \\
Arctic grayling (Thymallus arcticus) & 1 & 17 \\
Northern pike (Esox lucius) & 1 & 243 \\
Whitefish (unidentified species) & 0 & 3 \\
Alaska blackfish (Dallia pectorallis) & 34 & 2 \\
Lamprey (unidentified species) & 1,187 & 23 \\
Ninespine stickleback (Pungitius pungitius) & 2 & 2 \\
Burbot (Lota lota) & 0 & 2 \\
\hline
\end{tabular}




\section{Chum Salmon Captures}

A total of 99,415 and 43,979 juvenile chum salmon were captured in 2007 and 2008, respectively (table 1). In 2007, daily catches of chum salmon ranged from 29 fish on April 26 to 10,074 fish on May 19. In 2008, catches of chum salmon ranged from 1 fish on May 1 to 2,640 fish on June 2 (fig. 6). The highest catches occurred at night between 02:00 and 0:600 (fig. 7) and during increases in water stage (fig. 6). Juvenile chum salmon ranged in length from 30 to $46 \mathrm{~mm}$ fork length (FL) in 2007 $($ mean $=36 \mathrm{~mm} ; \mathrm{SD}= \pm 2.2 \mathrm{~mm}$ ), and from 28 to $55 \mathrm{~mm}$ FL in 2008 (mean = $38 \mathrm{~mm}$; SD = $\pm 3.3 \mathrm{~mm}$ ).
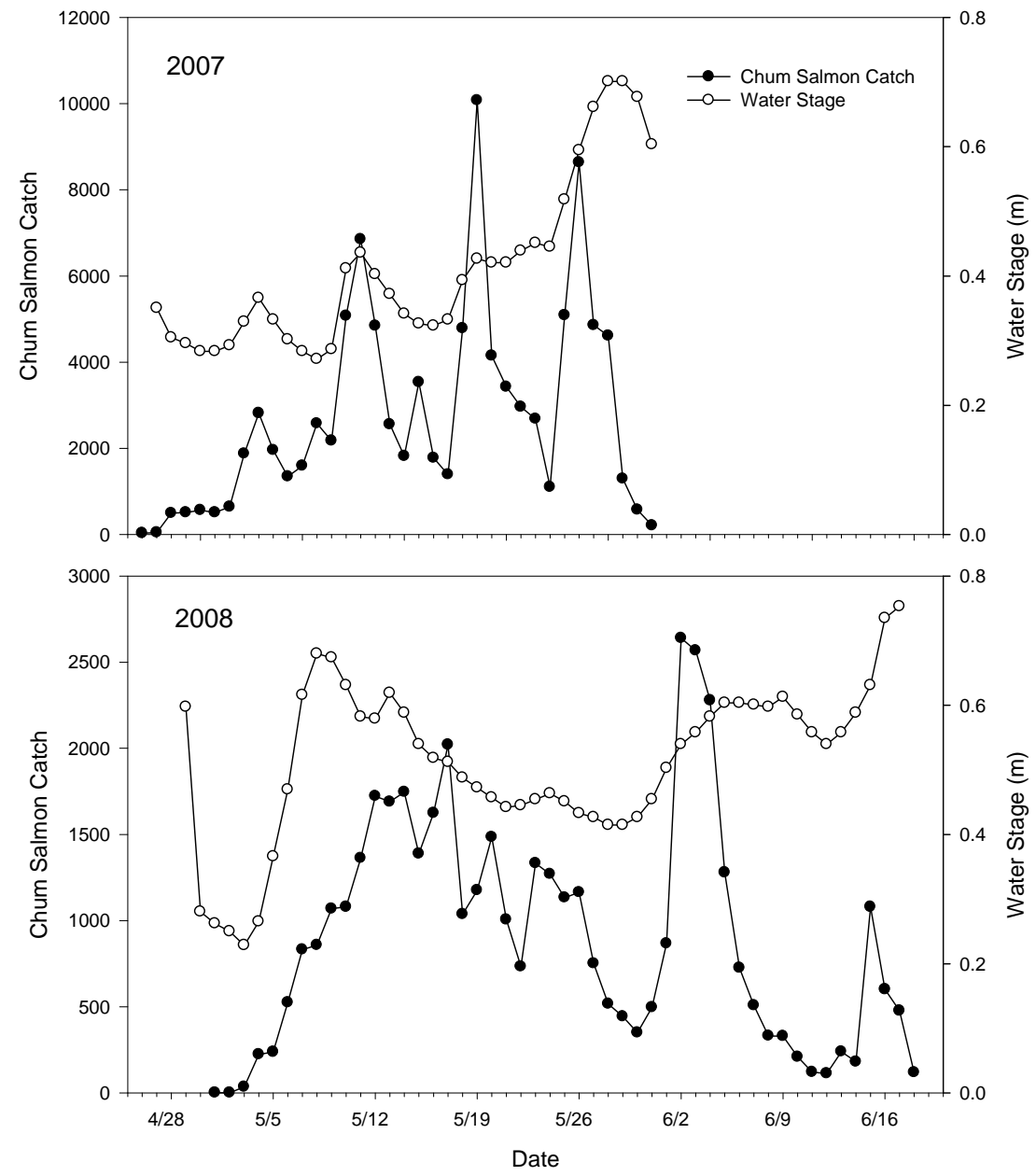

Figure 6. Daily catch of juvenile chum salmon and maximum daily water stage for the Kwethluk River, Alaska. 


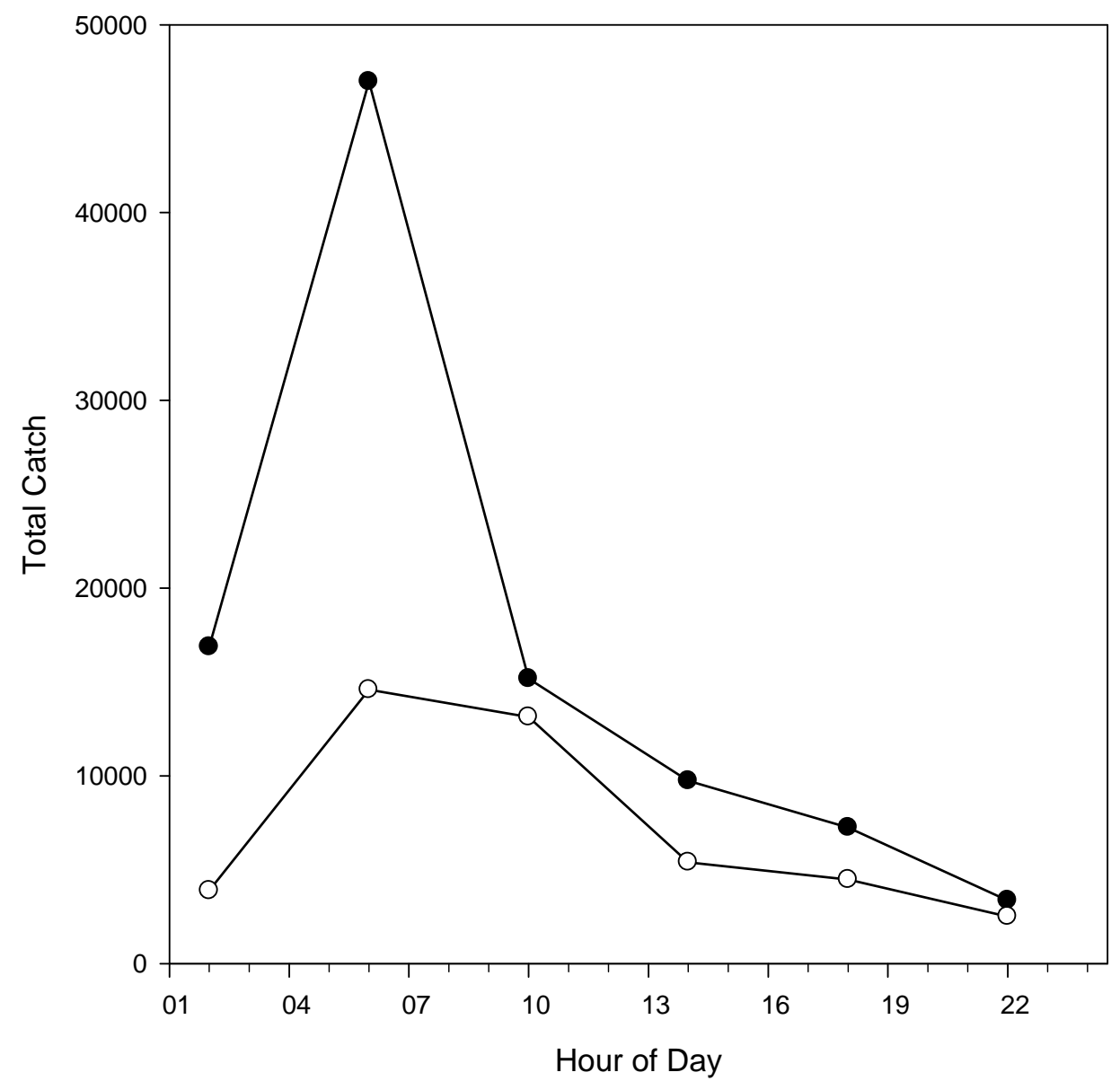

Figure 7. Total catch of juvenile chum salmon in 2007 (solid circles) and 2008 (open circles), Kwethluk River, Alaska.

\section{Other Salmonid Captures}

In 2007, peak catches of age-0 Chinook and sockeye salmon occurred between May 7 and May 29 (fig. 8). In 2008, peak age-0 Chinook salmon catches were much lower than 2007, and occurred between May 20 and June 6. Daily catches of age- 0 coho salmon were always less than 65 . Similar to catches of juvenile chum salmon, the catches of other salmon species increased during periods of increased water stage, and were highest between 02:00 and 06:00 (figs. 9 and 10). 

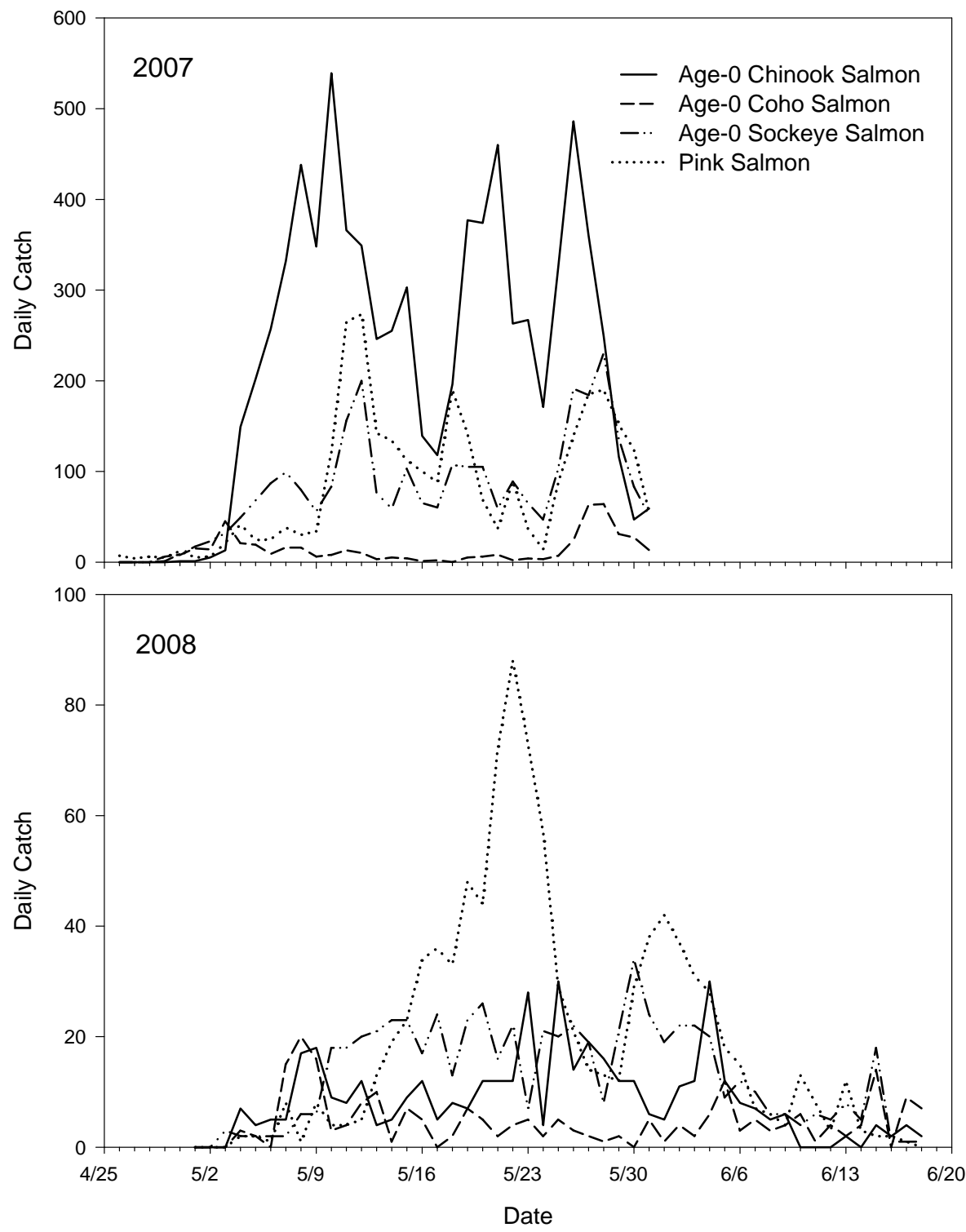

Figure 8. Daily catch of age-0 juvenile salmon on the Kwethluk River, Alaska. 

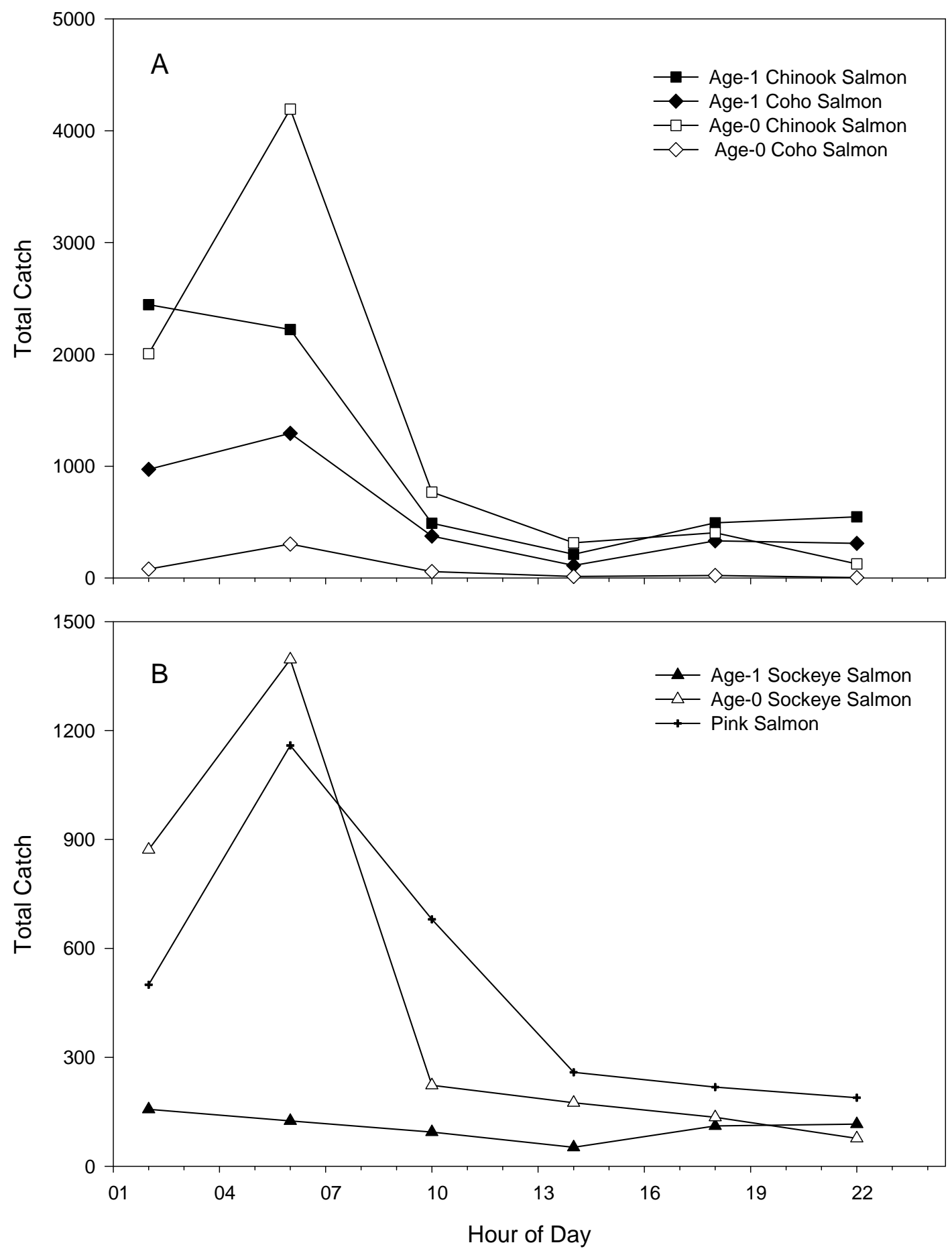

Figure 9. Total catch of Chinook and coho salmon (A) and sockeye and pink salmon (B) in the Kwethluk River, Alaska, 2007. 

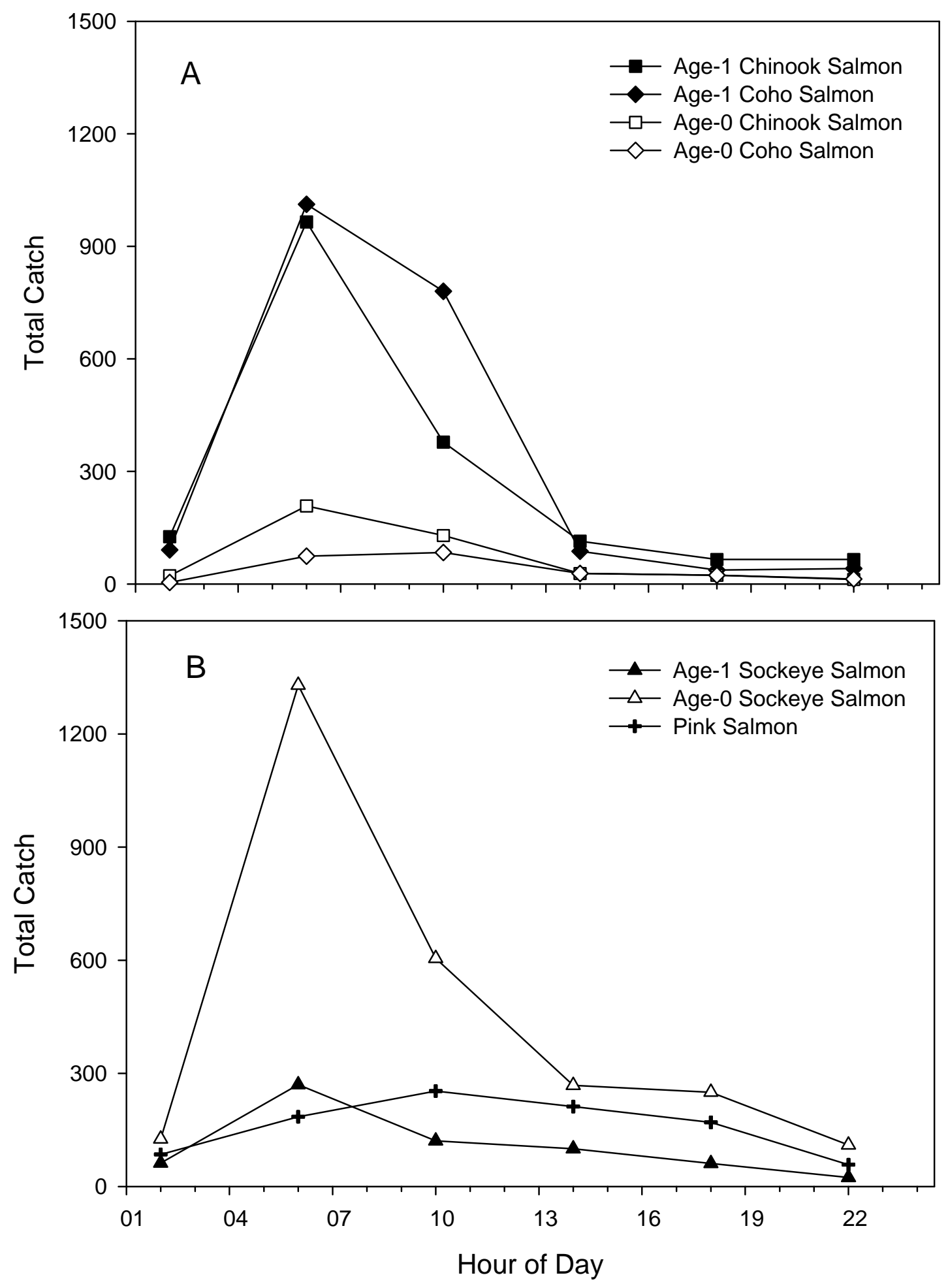

Figure 10. Total catch of juvenile Chinook and coho salmon (A) and sockeye and pink salmon (B) in the Kwethluk River, Alaska, 2008. 
Age-1+ Chinook, sockeye, and coho salmon catches were highest from May 8 to May 30 in 2007 and from May 28 to June 6 in 2008 (fig. 11). Peak catches of Chinook and coho salmon were on May 26 in 2007 (catches > 800), and on June 3 in 2008 (coho salmon > 250, Chinook salmon > 150) Daily catch of age-1+ sockeye salmon was usually less than 100 per day in both years and peak catches (> 100 fish) occurred on May 18 in 2007 and June 6 in 2008. Capture of all age-1+ salmon was closely associated with peaks in water stage (fig. 11) and during early morning (02:00 - 06:00) hours (figs. 9 and 10). Catch of pink salmon peaked on May 13 in 2007 and May 23 in 2008. As with other salmon species, pink salmon catches were highest during hours of low light (figs. 9 and 10) and high water events.
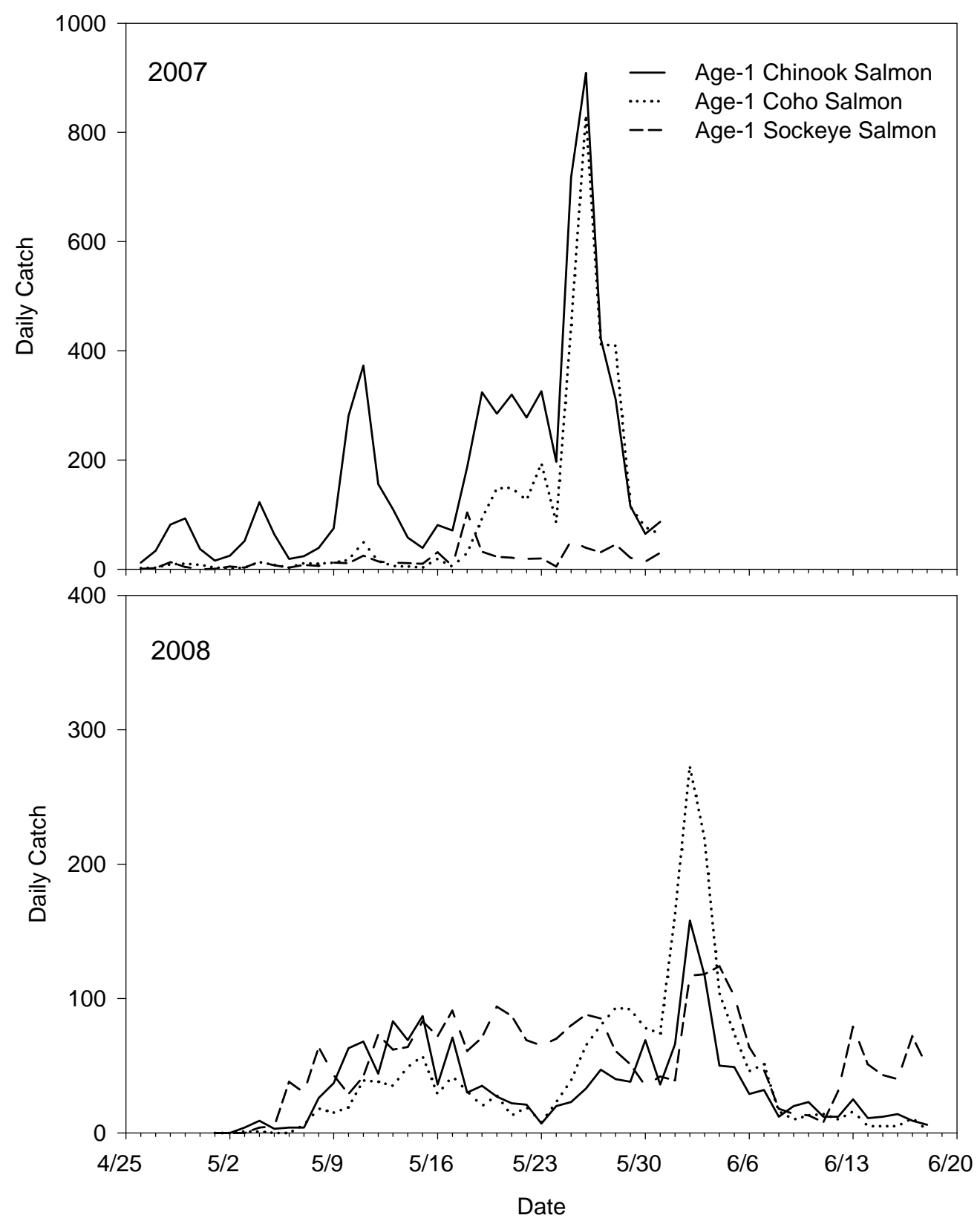

Figure 11. Daily catch of age 1+ juvenile salmon in the Kwethluk River, Alaska. 


\section{Estimates of Abundance and Survival of Chum Salmon}

We conducted 12 marking events in 2007, and 24 marking events in 2008 to determine the efficiency of our fish traps (table 2). In 2007, 20,950 juvenile chum salmon were marked and released and 415 were recaptured, which indicated an overall trap efficiency of 1.98 percent (table 2). Individual trap (Traps 1 and 2) catches varied, and as a general trend the trap with the highest daily catch had the fewest number of recaptures (appendix A). Traps 1 and 2 had overall efficiencies of 1.1 and 0.8 percent, respectively.

In 2008, 35,301 juvenile chum salmon were marked and released and 685 were recaptured, which indicated an overall trapping efficiency of 1.94 percent (table 2). Individual trap catches varied, but unlike in 2007, the trap with the highest catch in 2008 also had the highest number of recaptures (appendix A).

In 2007, the estimated abundance of downstream migrant juvenile chum salmon was 2.0 million fish (95 percent CI $=1.7-2.1$ million). In 2008, the estimated abundance of downstream migrant juvenile chum salmon was 2.9 million fish (95 percent $\mathrm{CI}=2.8-3.2$ million).

In 2006, PED for chum salmon (ages $0.2,0.3$, and 0.4 ) was 43.6 million eggs (SD $= \pm 5.9$ million). In 2007, PED was 56.0 million eggs ( $\mathrm{SD}= \pm 0.9$ million). Thus estimated egg-to-smolt survival for salmon migrating down stream was 4.6 percent ( $S D= \pm 0.71$ percent) in 2007 and 5.2 percent $(\mathrm{SD}= \pm 0.90$ percent) in 2008 . 
Table 2. Mark-recapture events, numbers of juvenile chum salmon marked and recaptured, and overall efficiency of inclined plane traps on the Kwethluk River, Alaska, 2007 and 2008.

\begin{tabular}{|c|c|c|c|c|}
\hline Year & Event & Marks & Recaptures & $\begin{array}{l}\text { Efficiency } \\
\text { (percent) }\end{array}$ \\
\hline \multirow[t]{12}{*}{2007} & 1 & 782 & 12 & 1.53 \\
\hline & 2 & 1,463 & 18 & 1.23 \\
\hline & 3 & 1,102 & 17 & 1.54 \\
\hline & 4 & 2,229 & 37 & 1.66 \\
\hline & 5 & 1,869 & 27 & 1.44 \\
\hline & 6 & 3,102 & 102 & 3.29 \\
\hline & 7 & 1,592 & 22 & 1.38 \\
\hline & 8 & 911 & 20 & 2.20 \\
\hline & 9 & 3,123 & 72 & 2.31 \\
\hline & 10 & 1,864 & 29 & 1.56 \\
\hline & 11 & 2,192 & 41 & 1.87 \\
\hline & 12 & 721 & 18 & 2.50 \\
\hline \multicolumn{2}{|l|}{ Total } & 20950 & 415 & 1.98 \\
\hline Year & Event & Marks & Recaptures & $\begin{array}{r}\text { Efficiency } \\
\text { (percent) }\end{array}$ \\
\hline \multirow[t]{24}{*}{2008} & 1 & 1,276 & 10 & 0.78 \\
\hline & 2 & 793 & 6 & 0.76 \\
\hline & 3 & 1,011 & 8 & 0.79 \\
\hline & 4 & 1,088 & 8 & 0.74 \\
\hline & 5 & 1,421 & 10 & 0.70 \\
\hline & 6 & 1,576 & 10 & 0.63 \\
\hline & 7 & 1,484 & 18 & 1.21 \\
\hline & 8 & 1,696 & 27 & 1.59 \\
\hline & 9 & 1,221 & 22 & 1.80 \\
\hline & 10 & 1,524 & 17 & 1.12 \\
\hline & 11 & 2,816 & 50 & 1.78 \\
\hline & 12 & 1,871 & 53 & 2.83 \\
\hline & 13 & 1,705 & 25 & 1.47 \\
\hline & 14 & 2,138 & 47 & 2.20 \\
\hline & 15 & 2,244 & 75 & 3.34 \\
\hline & 16 & 1,295 & 25 & 1.93 \\
\hline & 17 & 813 & 17 & 2.09 \\
\hline & 18 & 942 & 20 & 2.12 \\
\hline & 19 & 2,351 & 55 & 2.34 \\
\hline & 20 & 2,871 & 88 & 3.07 \\
\hline & 21 & 1,249 & 30 & 2.40 \\
\hline & 22 & 644 & 34 & 5.28 \\
\hline & 23 & 564 & 18 & 3.19 \\
\hline & 24 & 708 & 12 & 1.69 \\
\hline Total & & 35,301 & 685 & 1.94 \\
\hline
\end{tabular}




\section{Temperature and Water Stage Fluctuations}

Minimum and maximum air temperature fluctuated from $-5{ }^{\circ} \mathrm{C}$ to $20{ }^{\circ} \mathrm{C}$ in 2007 and from $-12{ }^{\circ} \mathrm{C}$ to $21^{\circ} \mathrm{C}$ in 2008 (appendix B). Water temperature ranged from a low of $1{ }^{\circ} \mathrm{C}$ to a high of $10{ }^{\circ} \mathrm{C}$ in 2007 and from $0{ }^{\circ} \mathrm{C}$ to $13^{\circ} \mathrm{C}$ in 2008 (fig. 12, appendix B). Water stage ranged from a low of $0.27 \mathrm{~m}$ on May 9 to a high of $0.70 \mathrm{~m}$ on May 30 in 2007 and from $0.23 \mathrm{~m}$ on May 3 to $0.75 \mathrm{~m}$ on June 17 in 2008 (fig. 12).

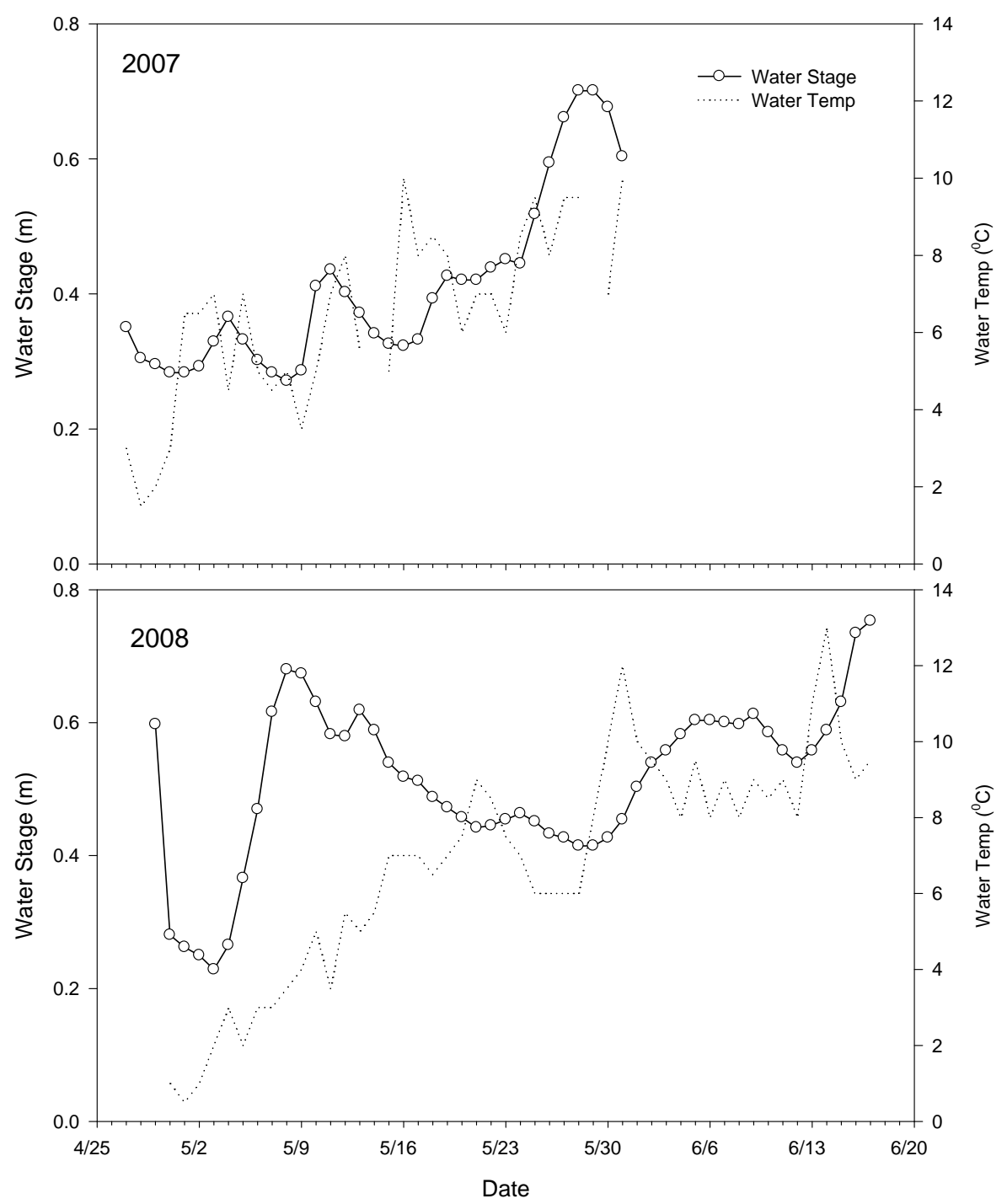

Figure 12. Daily water stage and water temperature for the Kwethluk River, Alaska, 2007-08. 


\section{Discussion}

The study described here provides the first estimates of smolt abundance and egg-to-smolt survival in the Kuskokwim River watershed and the Arctic-Yukon-Kuskokwim region. Further, this is one of very few studies to quantify the abundance of juvenile chum salmon in Alaska. Our survival estimates of 4.6 and 5.2 percent fall within the lower range of values previously reported (table 3 ). The survival of chum salmon from spawning to emergence and migration varies widely among streams and among years within a stream (Salo, 1991; table 3).

Bradford (1995) reported that egg-to-smolt survival of chum salmon ranges from 7 to 9 percent and estimates of greater variability result from the analysis of small coastal creeks in Alaska and British Columbia that are subject to extreme fluctuations in flow. Beacham and Starr (1982) used 19 years of data on chum salmon adult returns, PED, and smolt abundance to examine the relation between environmental variables and egg-to-smolt survival for chum salmon in the Fraser River, British Columbia. Egg-to-smolt survival was inversely related to the amount of winter rainfall, and most of the variability in survival was attributable to interactions among temperature, rainfall, and egg abundance. During the 19 years that Beacham and Starr (1982) quantified egg-to-smolt survival, estimates varied six fold. Similarly, in 14 years of sampling, Parker (1962) reported egg-to-smolt survival ranging from 1.0 to 22.0 percent. Given this broad range in survival estimates, long-term studies are needed to assess egg-to-smolt survival so that estimates can be reliably used in models of population dynamics.

Table 3. Egg-to-smolt survival of chum salmon determined in this and other studies.

\begin{tabular}{|c|c|c|c|c|}
\hline \multirow[b]{2}{*}{ Location } & \multirow[b]{2}{*}{$\begin{array}{c}\text { Years } \\
\text { sampled }\end{array}$} & \multicolumn{2}{|c|}{ Survival } & \multirow[b]{2}{*}{ Source } \\
\hline & & $\begin{array}{l}\text { Range } \\
\text { ( percent) }\end{array}$ & $\begin{array}{c}\text { Mean } \\
\text { ( percent) }\end{array}$ & \\
\hline Kwethluk R. AK & 2 & $4.6-5.2$ & 4.9 & This study \\
\hline Disappearance Cr. AK & 2 & $8.7-16.9$ & 12.8 & Wright $(1964)^{1}$ \\
\hline Fraser R. BC & 19 & $5.7-35.4$ & 14.2 & Beacham and Starr (1982) \\
\hline Big Qualicum R. BC & 4 & $5.0-17.0$ & 11.2 & Lister and Walker (1966) \\
\hline Nile Cr. BC & 4 & $0.1-7.0$ & 1.5 & Wickett $(1952)^{1}$ \\
\hline Hooknose Cr. BC & 14 & $1.0-22.0$ & 8.5 & Parker (1962) \\
\hline Inches Cr. BC & 4 & $1.6-18.8$ & 8.9 & Fedorenko and Bailey (1980) \\
\hline Bolshaya R. Russia & 7 & $0.7-4.2$ & 2.4 & Semko (1954) ${ }^{1}$ \\
\hline Memu R. Japan & 3 & $16.2-34.4$ & 27.6 & Nagasawa and Sano (1961) ${ }^{1}$ \\
\hline
\end{tabular}


In our study on the Kwethluk River, fluctuations in water depth (and hence, discharge) appeared to be the largest factor influencing the rate of migration of juvenile chum salmon (fig. 6). Similar to the findings in other studies on juvenile salmon migration (Hoar, 1958; Kobayashi and Ishikawa, 1964), the migration rate of Kwethluk River juvenile salmon abundance increased during high water events, and as previously reported (McDonald, 1960; Volobuyev, 1984), peak migration timing occurred during early morning (02:00 - 06:00). Peak migration during our field experiments occurred from mid-May through mid-June, which coincides with timing of juvenile chum salmon migration from Yukon River tributaries (Martin and others, 1986). In 2007, juvenile chum salmon were captured the first day of trap operation on April 26, indicating an early to mid-April migration time for some juveniles. In 2008, juvenile chum salmon were not captured until May $1-2$ days after trap installation - which was likely due to the later break-up and colder water temperatures during that year (appendix B). In addition, fluctuation in river height due to late snow melt at high elevations likely affected the timing of peak juvenile chum salmon migration between sampling years.

This study was intended, in part, to develop and test methods for estimating smolt abundances of salmon in a Kuskokwim River tributary. Although many studies and methods have been developed for use elsewhere (see Volkhardt and others, 2007), methods of this type have not been attempted in the AYK region. Differences in duration of ice cover, break-up dates, size of rivers, and difficulty of access within this region prompted the need for modifications to previously developed protocols and methods. Our previous experience operating inclined plane traps in this region led us to make several modifications to the traps as described by Todd (1994). The trap modifications and design were relatively untested previous to this project. After the first year of sampling, a few concerns with the sampling protocol needed to be addressed. The variability in individual trap efficiency (appendix A) was of greatest concern. In 2007, the trap with the highest catch of juvenile chum salmon caught the lowest number of recaptures. This indicates that upon release, the marked juveniles did not mix back into the population effectively, which is problematic for the assumptions of a mark-recapture experiment. In 2007, marked fish were kept in holding pens at the trap site until just prior to release. The fish were then dip netted into buckets and transported upstream, where they were immediately released. As a potential remedy for this problem, in 2008 we placed holding pens on both sides of the river at the release site. Marked fish were allowed to recover for 6 to 8 hours and then allowed to resume migration of their own volition. In 2008, individual trap catches were as expected: the trap with the highest catch also had the highest number of recaptures, indicating that the 2007 trap efficiency issues were due to method of release. This result also emphasizes the importance of using two traps for this project. If only one trap had been used, the 2007 bias of marked individuals not mixing properly into the main population of downstream migrants would not have been detected and, as a result, abundance estimates would be misleading.

Predation within the live boxes of the traps may have lead to biases in the estimation of trapping efficiency. In 2007, we observed active predation of chum salmon by Chinook and coho salmon. To reduce the potential for predation, we installed predator screens in the live boxes for the 2008 field season. The screens were designed to separate the larger predatory juvenile salmon (age 1+ Chinook and coho) from the age-0 juveniles.

Trap efficiency appeared to vary with changes in water stage, both overall and between traps. One trap was more efficient during high-water events, while the other trap was more efficient during times of low water stage. One explanation for this could be that during times of high water discharge, juvenile chum salmon preferred the shallower water where one trap was positioned; conversely, when water was low and clear, juveniles preferred the deeper channel, where the other trap was located. In 2007, more than double the total number (compared to 2008) of juvenile chum salmon were captured; 
however, the abundance estimate was approximately 1 million fish lower than in 2008. The lower water levels and higher trap efficiencies in 2007 are the likely cause for this result. Similar findings of reduced trap efficiency associated with high water were reported by Todd (1994), who used inclined-plane smolt traps on the Kasilof River, Kenai Peninsula, Alaska.

This project design proved effective for sampling juvenile salmon with an immediate seaward migration, and may be useful in estimating abundance of other salmon species. Application of this method to estimate the abundance of other salmon species with multiple age classes is possible if fish rear exclusively upstream of the trapping location. If juvenile salmon migrate downstream to rear in other locations, estimates of freshwater survival would need to account for survival in non-natal habitats. In addition, the population size would have to be large enough to provide an adequate number of marks for the abundance estimation.

In a review of survival rates of Pacific salmon, Bradford (1995) found that the freshwater stage is important in determining recruitment of salmon, even for pink and chum salmon that spend most of their life in the sea. Future monitoring of juvenile salmon abundance, coupled with adult salmon monitoring, would provide needed information to expand our ability to determine the relative importance of mortality in freshwater habitats of the Kwethluk River.

\section{Summary}

Through this research, we were able to produce the first estimates of egg-to-smolt survival and determine migration timing for juvenile chum salmon in a remote western Alaska river. Environmental factors strongly influenced both timing and rate of migration, and emphasize the strong environmental control on fish populations in northern latitude habitats. This research is a first step towards predicting early freshwater production of juvenile chum salmon in data limited areas, such as the Kuskokwim watershed, and highlights just how important the freshwater environment can be to the overall production of chum salmon in the Arctic-Yukon-Kuskokwim Region.

\section{Acknowledgments}

This research was possible due to the cooperation and support of the U.S Fish and Wildlife Service and the Organized Village of Kwethluk (OVK). In particular, we thank the field crew: Wilson Berlin, Adam Fisher, John Fisher, David Guy, Tim Michaels, Nathan Nicolai, and Brian Spein from OVK, and Jason Baker, Libby Benolkin, Andy Ramey, and Vanessa von Biela from USGS. Steve Miller, Frank Harris, and Darryl Sipary of the USFWS provided valuable advice and field support. We thank USGS colleague Mark Carr for constructing and repairing the inclined-plane traps, and Rod Simmons, Bruce Hansen, and Karen Oakley for reviews that improved this report. 


\section{References Cited}

Arctic-Yukon-Kuskokwim Sustainable Salmon Initiative, 2006, Arctic-Yukon-Kuskokwim Salmon Research and Restoration Plan: Bering Sea Fishermen's Association. Anchorage, AK, 85 p.

Beacham, T.D., and Starr, P., 1982, Population biology of chum salmon (Oncorhynchus keta) from the Fraser River, British Columbia: Fishery Bulletin, v. 80, p. 813-825.

Beamish, R.J., and Sweeting, R.M., 2009, The history of surprises associated with Pacific salmon returns signals that critical information is missing from our understanding of their population dynamics, in Krueger, C.C., and Zimmerman, C.E., editors, Pacific salmon: ecology and management of western Alaska’s populations: American Fisheries Society Symposium 70, Bethesda, Maryland, p. 1159-1168.

Bradford, M.J., 1995, Comparative review of Pacific salmon survival rates: Canadian Journal of Fisheries and Aquatic Sciences, v. 52, p. 1327-1338.

Brown, T.G., and Hartman, G.F., 1988, Contribution of seasonally flooded lands and minor tributaries to the production of coho salmon in Carnation Creek, British Columbia: Transactions of the American Fisheries Society, v. 117, p. 546-551.

Carlson, S.R., Coggins, L.G. Jr., and Swanton, C.O., 1998, Simple stratified design for mark-recapture estimation of salmon smolt abundance: Alaska Fisheries Research Bulletin, v. 5, p. 88-102.

Clark, R.A., Bernard, D.R., and Fleischman, S.J., 2009, Stock-recruitment analysis for escapement goal development: a case study of Pacific salmon in Alaska, in Krueger, C.C., and Zimmerman, C.E., editors, Pacific salmon: ecology and management of western Alaska's populations: American Fisheries Society Symposium 70, Bethesda, Maryland, p. 743-758.

Fedorenko, A.Y., and Bailey, D.D., 1980, Inches Creek chum pilot project: Canadian Manuscript Report of Fisheries and Aquatic Sciences, no. 1562.

Gilk, S.E., Templin, W.D., Molyneaux, D.B., Hamazaki, T., and Pawluk, J.A., 2005, Characteristics of fall chum salmon Oncorhynchus keta in the Kuskokwim River drainage: Alaska Department of Fish and Game, Fisheries Data Series Number 05-56, Anchorage.

Hartman, G.F., Andersen, B.C., and Scrivener, J.C., 1982, Seaward movement of coho salmon (Oncorhynchus kisutch) fry in Carnation Creek, an unstable coastal stream in British Columbia: Canadian Journal of Fisheries and Aquatic Science, v. 39, p. 588-597.

Hilborn, R., Bue, B.G., and Sharr, S., 1999, Estimating spawning escapements from periodic counts: a comparison of methods: Canadian Journal of Fisheries and Aquatic Science, v. 56, p. 888-896.

Hoar, W.S., 1958, The evolution of migratory behavior among juvenile salmon of the genus

Oncorhynchus: Journal of the Fisheries Research Board of Canada, v. 15, p. 391-428.

Kobayahsi, T., Ishikawa, Y., 1964, An ecological study on the salmon fry, Oncorhynchus keta (Walbaum). VIII: the growth and feeding habit of the fry during seaward migration: Scientific Reports of the Hokkaido Salmon Hatchery, v. 18, p. 7-12.

Letcher, B.H., Gries, G., and Juanes, F., 2002, Survival of stream-dwelling Atlantic salmon: effects of life history variation, season, and age: Transactions of the American Fisheries Society, v. 131, p. 838-854.

Linderman, J.C., Jr., and Bergstrom, D.J., 2009, Kuskokwim management area: salmon escapement, harvest, and management, in Krueger, C.C., and Zimmerman, C.E., editors, Pacific salmon: ecology and management of western Alaska's populations: American Fisheries Society Symposium 70, Bethesda, Maryland, p. 541-600.

Lister, D.B., and Walker, C.E., 1966, The effect of flow control on freshwater survival of chum, coho, and Chinook salmon in the Big Qualicum River: Canadian Fish Culturalist, v. 37, p. 3-25. 
Martin, D.J., Glass, D.R., Whitmus, C.J., Simenstad, C.A., Milward, D.A., Volk, E.C., Stevenson, M.L., Nunes, P., Savoie, M., and Grotefendt, R.A., 1986, Distribution, seasonal abundance, and feeding dependencies of juvenile salmon and non-salmonid fishes in the Yukon River Delta: Final Report, Outer Continental Shelf Environmental Assessment Program, Research Unit 660.

McDonald, J., 1960, The behavior of Pacific salmon fry during their downstream migration to freshwater and saltwater nursery areas: Journal of the Fisheries Research Board of Canada, v. 17, p. 655-676.

Miller, S.J., Harper, K.C., and Spencer, D.J., 2007, Abundance and run timing of adult Pacific salmon in the Kwethluk River, Yukon Delta National Wildlife Refuge, Alaska, 2006: U.S. Fish and Wildlife Service, Alaska Fisheries Data Series Number 2007-9.

Miller, S.J., Harper, K.C., and Sanders, S., 2009, Abundance and run timing of adult Pacific salmon in the Kwethluk River, Yukon Delta National Wildlife Refuge, Alaska, 2008: U.S. Fish and Wildlife Service, Alaska Fisheries Data Series Number 2007-10.

Mobrand, L.E., Lichatowich, J.A., Lestelle, L.C., and Vogel, T.S., 1997, An approach to describing ecosystems performance "through the eyes of salmon": Canadian Journal of Fisheries and Aquatic Science, v. 54, p. 2964-2973.

Moussalli, E., and Hilborn, R., 1986, Optimal stock size and harvest rate in multistage life history models: Canadian Journal of Fisheries and Aquatic Science, v. 43, p. 135-141.

Nagasawa, A., and Sano, S., 1961, Some observations on the downstream chum salmon fry (O. keta) counted in the natural spawning ground at Memu Stream, 1957-1959: Scientific Reports of the Hokkaido Salmon Hatchery, v. 16, p. 107-125.

National Research Council, 2005, Developing a research and restoration plan for Arctic-YukonKuskokwim (western Alaska) salmon: The National Academies Press, Washington, DC.

Orciari, R., Leonard, G.H., Mysling, D.J., and Schluntz, E.C., 1994, Survival, growth, and smolt production of Atlantic salmon stocked as fry in a southern New England stream: North American Journal of Fisheries Management, v. 14, p. 588-606.

Parker, R.R, 1962, A concept of the dynamics of pink salmon populations. In Symposium on Pink Salmon, in Wilimovsky, N.J., editor, H.R. MacMillan Lectures in Fisheries: Institute of Fisheries, University of British Columbia, Vancouver, B.C.

Roper, B., and Scarnecchia, D.L., 1996, A comparison of trap efficiencies for wild and hatchery age-0 Chinook salmon: North American Journal of Fisheries Management, v. 16, p. 214-217.

Salo, E.O., 1991, Life history of chum salmon (Oncorhynchus keta), in C. Groot, and L. Margolis editors, Pacific Salmon Life Histories: UBC Press, Vancouver, B.C., p. 232-389.

Seber, G.A.F, 1982, The estimation of animal abundance and related parameters, $2^{\text {nd }}$ edition: Macmillan Publishing Co. Inc, New York, NY.

Semko, R.S., 1954, The stocks of west Kamchatka salmon and their commercial utilization: Fisheries Research Board of Canada Translation Series 288.

Solazzi, M.F., Nicholson, T.E., Johnson, S.L., and Rodgers, J.D., 2000, Effects of increasing winter habitat on abundance of salmonids in two coastal Oregon streams: Canadian Journal of Fisheries and Aquatic Sciences, v. 57, p. 906-914.

Thedinga, J.F., Murphy, M.L., Johnson, S.W., Lorenz, J.M., and Koski, K.V., 1994, Determination of salmonid smolt yield with rotary-screw traps in the Situk River, Alaska, to predict effects of glacial flooding: North American Journal of Fisheries Management, v. 14, p. 837-851.

Todd, G.L., 1994, A lightweight, incline-plane trap for sampling salmon smolts in rivers: Alaska Fisheries Research Bulletin, v. 1, p. 168-173. 
Tsumura, K., and Hume, J.M.B., 1986, Two variations of a salmonid smolt trap for small rivers: North American Journal of Fisheries Management, v. 6, p. 272-276.

Wagner, H.H., Wallace, R.L., and Campbell, H.J., 1963, The seaward migration and return of hatcheryreared steelhead trout, Salmo gairdneri Richardson, in the Alsea River, Oregon: Transactions of the American Fisheries Society, v. 92, p. 202-210.

Wickett, W.P., 1952, Production of chum and pink salmon in a controlled stream: Fishery Research Board of Canada, Progress Report Pacific Coast Station, v. 93, p. 7-9.

Wright, A.T, 1964, Studies to determine optimum escapement of pink and chum salmon in Alaska. Part 9: A study of the carrying capacity of pink and chum salmon spawning areas in Alaska: Alaska Department of Fish and Game, Juneau, AK, 11 p.

Volkhardt, G.C., Johnson, S.L., Miller, B.A., Nickelson, T.E., and Seiler, D.E., 2007, Rotary screw traps and inclined plane screen traps, in Johnson, D.H., Schrier, B.M., O’Neal, J.S., Knutzen, J.A., Augerot, X., O’Neil, T.A., and Pearsons, T.N., Salmonid field protocols handbook: techniques for assessing status and trends in salmon and trout populations: American Fisheries Society, Bethesda, MD, p. 235-266.

Volobuyev, V.V., 1984, Spawning characteristics and ecology of young chum salmon, Oncorhynchus keta, in the Tauy River Basin (northern Okhotsk Sea): Journal of Ichthyology, v. 24, p. 156-173. 


\section{Appendix A. Mark-recapture data for fish traps used in the Kwethluk River, Alaska, 2007 and 2008.}

[T1, trap 1; T2, trap 2]

\begin{tabular}{|c|c|c|c|c|c|c|c|c|c|}
\hline Year & Event & $\begin{array}{c}\text { Marks } \\
\text { Released }\end{array}$ & $\begin{array}{c}\text { Unmarked } \\
\text { Catch }\end{array}$ & $\begin{array}{c}\text { T1 } \\
\text { Catch }\end{array}$ & $\begin{array}{c}\text { T2 } \\
\text { Catch }\end{array}$ & $\begin{array}{c}\text { T1 } \\
\text { Recaps }\end{array}$ & $\begin{array}{c}\text { T2 } \\
\text { Recaps }\end{array}$ & $\begin{array}{c}\text { T1 } \\
\text { Efficiency } \\
\text { percent }\end{array}$ & $\begin{array}{c}\text { T2 } \\
\text { Efficiency } \\
\text { percent }\end{array}$ \\
\hline \multirow[t]{12}{*}{2007} & 1 & 782 & 1,870 & 1,148 & 722 & 10 & 2 & 1.28 & 0.26 \\
\hline & 2 & 1,463 & 2,041 & 1,314 & 727 & 15 & 3 & 1.03 & 0.21 \\
\hline & 3 & 1,102 & 2,687 & 1,671 & 1,016 & 13 & 4 & 1.18 & 0.36 \\
\hline & 4 & 2,229 & 7,236 & 4,300 & 2,936 & 21 & 16 & 0.94 & 0.72 \\
\hline & 5 & 1,869 & 6,835 & 2,798 & 4,037 & 10 & 17 & 0.54 & 0.91 \\
\hline & 6 & 3,102 & 2,541 & 1,011 & 1,530 & 66 & 36 & 2.13 & 1.16 \\
\hline & 7 & 1,592 & 1,087 & 251 & 836 & 17 & 5 & 1.07 & 0.31 \\
\hline & 8 & 911 & 4,494 & 1,848 & 2,646 & 14 & 6 & 1.54 & 0.66 \\
\hline & 9 & 3,123 & 4,184 & 1,304 & 2,880 & 24 & 48 & 0.77 & 1.54 \\
\hline & 10 & 1,864 & 2,746 & 884 & 1,862 & 12 & 17 & 0.64 & 0.91 \\
\hline & 11 & 2,192 & 8,632 & 2,833 & 5,799 & 16 & 25 & 0.73 & 1.14 \\
\hline & 12 & 721 & 574 & 329 & 245 & 17 & 1 & 2.36 & 0.14 \\
\hline Total & & 20,950 & 44,927 & 19,691 & 25,236 & 235 & 180 & 1.18 & 0.69 \\
\hline
\end{tabular}




\section{Appendix A. (Continued)}

\begin{tabular}{|c|c|c|c|c|c|c|c|c|c|}
\hline Year & Event & $\begin{array}{c}\text { Marks } \\
\text { Released }\end{array}$ & $\begin{array}{c}\text { Unmarked } \\
\text { Catch }\end{array}$ & $\begin{array}{c}\text { T1 } \\
\text { Catch }\end{array}$ & $\begin{array}{c}\text { T2 } \\
\text { Catch }\end{array}$ & $\begin{array}{c}\text { T1 } \\
\text { Recaps }\end{array}$ & $\begin{array}{c}\text { T2 } \\
\text { Recaps }\end{array}$ & $\begin{array}{c}\text { T1 } \\
\text { Efficiency } \\
\text { percent }\end{array}$ & $\begin{array}{c}\text { T2 } \\
\text { Efficiency } \\
\text { percent }\end{array}$ \\
\hline \multirow[t]{24}{*}{2008} & 1 & 1,276 & 858 & 664 & 194 & 6 & 4 & 0.47 & 0.31 \\
\hline & 2 & 793 & 1,069 & 837 & 232 & 5 & 1 & 0.63 & 0.13 \\
\hline & 3 & 1,011 & 1,080 & 841 & 239 & 7 & 1 & 0.69 & 0.10 \\
\hline & 4 & 1,088 & 1,362 & 1,001 & 361 & 4 & 4 & 0.37 & 0.37 \\
\hline & 5 & 1,421 & 1,722 & 1,410 & 312 & 9 & 1 & 0.63 & 0.07 \\
\hline & 6 & 1,576 & 1,690 & 1,149 & 541 & 6 & 4 & 0.38 & 0.25 \\
\hline & 7 & 1,484 & 1,746 & 1,142 & 604 & 13 & 5 & 0.88 & 0.34 \\
\hline & 8 & 1,696 & 1,388 & 815 & 573 & 18 & 9 & 1.06 & 0.53 \\
\hline & 9 & 1,221 & 1,624 & 992 & 632 & 7 & 15 & 0.57 & 1.23 \\
\hline & 10 & 1,524 & 2,021 & 889 & 1,132 & 15 & 2 & 0.98 & 0.13 \\
\hline & 11 & 2,816 & 1,176 & 600 & 576 & 24 & 26 & 0.85 & 0.92 \\
\hline & 12 & 1,871 & 1,006 & 410 & 596 & 19 & 34 & 1.02 & 1.82 \\
\hline & 13 & 1,705 & 1,333 & 812 & 521 & 8 & 17 & 0.47 & 1.00 \\
\hline & 14 & 2,138 & 1,133 & 453 & 680 & 16 & 31 & 0.75 & 1.45 \\
\hline & 15 & 2,244 & 751 & 282 & 469 & 19 & 56 & 0.85 & 2.50 \\
\hline & 16 & 1,295 & 443 & 134 & 309 & 6 & 19 & 0.46 & 1.47 \\
\hline & 17 & 813 & 497 & 154 & 343 & 10 & 7 & 1.23 & 0.86 \\
\hline & 18 & 942 & 2,640 & 1,520 & 1,120 & 9 & 11 & 0.96 & 1.17 \\
\hline & 19 & 2,351 & 2,567 & 1,912 & 655 & 36 & 19 & 1.53 & 0.81 \\
\hline & 20 & 2,871 & 1,279 & 861 & 418 & 60 & 28 & 2.09 & 0.98 \\
\hline & 21 & 1,249 & 508 & 286 & 222 & 25 & 5 & 2.00 & 0.40 \\
\hline & 22 & 644 & 330 & 205 & 125 & 26 & 8 & 4.04 & 1.24 \\
\hline & 23 & 564 & 113 & 71 & 42 & 14 & 4 & 2.48 & 0.71 \\
\hline & 24 & 708 & 601 & 382 & 219 & 6 & 6 & 0.85 & 0.85 \\
\hline Total & & 35,301 & 28,937 & 17,822 & 11,115 & 368 & 317 & 1.09 & 0.82 \\
\hline
\end{tabular}


Appendix B. Daily catches of juvenile chum salmon along with readings for water stage, maximum water temperature, and minimum and maximum air temperature, Kwethluk River, 2007 and 2008.

\begin{tabular}{|c|c|c|c|c|c|c|}
\hline Year & Date & $\begin{array}{l}\text { Chum } \\
\text { Catch }\end{array}$ & $\begin{array}{c}\text { Max Water Stage } \\
\text { (meters) }\end{array}$ & $\begin{array}{c}\text { Max Water Temp } \\
\left({ }^{\circ} \mathrm{C}\right)\end{array}$ & $\begin{array}{c}\text { Min Air Temp } \\
\left({ }^{\circ} \mathrm{C}\right)\end{array}$ & $\begin{array}{c}\text { Max Air Temp } \\
\left({ }^{\circ} \mathrm{C}\right)\end{array}$ \\
\hline 2007 & $4 / 26 / 2007$ & 29 & & & & \\
\hline 2007 & $4 / 27 / 2007$ & 46 & 0.35 & 3.0 & -5 & \\
\hline 2007 & $4 / 28 / 2007$ & 495 & 0.30 & 1.5 & -4 & \\
\hline 2007 & $4 / 29 / 2007$ & 509 & 0.30 & 2.0 & -3 & \\
\hline 2007 & $4 / 30 / 2007$ & 563 & 0.28 & 3.0 & & \\
\hline 2007 & $5 / 1 / 2007$ & 510 & 0.28 & 6.5 & & \\
\hline 2007 & $5 / 2 / 2007$ & 641 & 0.29 & 6.5 & -2 & 12 \\
\hline 2007 & $5 / 3 / 2007$ & 1,873 & 0.33 & 7.0 & 0 & 13 \\
\hline 2007 & $5 / 4 / 2007$ & 2,815 & 0.37 & 4.5 & -2 & 4 \\
\hline 2007 & $5 / 5 / 2007$ & 1,956 & 0.33 & 7.0 & -1 & 9 \\
\hline 2007 & $5 / 6 / 2007$ & 1,344 & 0.30 & 5.0 & -1 & 7 \\
\hline 2007 & $5 / 7 / 2007$ & 1,592 & 0.28 & 4.5 & 0 & 5 \\
\hline 2007 & $5 / 8 / 2007$ & 2,574 & 0.27 & 5.0 & 1 & 7 \\
\hline 2007 & $5 / 9 / 2007$ & 2,174 & 0.29 & 3.5 & 0 & \\
\hline 2007 & $5 / 10 / 2007$ & 5,074 & 0.41 & 5.0 & 1 & 11 \\
\hline 2007 & $5 / 11 / 2007$ & 6,852 & 0.44 & 7.0 & -1 & 14 \\
\hline 2007 & $5 / 12 / 2007$ & 4,842 & 0.40 & 8.0 & & \\
\hline 2007 & $5 / 13 / 2007$ & 2,557 & 0.37 & 5.5 & & \\
\hline 2007 & $5 / 14 / 2007$ & 1,816 & 0.34 & & 2 & 0 \\
\hline 2007 & $5 / 15 / 2007$ & 3,534 & 0.33 & 5.0 & 3 & 14 \\
\hline 2007 & $5 / 16 / 2007$ & 1,777 & 0.32 & 10.0 & -2 & 20 \\
\hline 2007 & $5 / 17 / 2007$ & 1,390 & 0.33 & 8.0 & 6 & 18 \\
\hline 2007 & $5 / 18 / 2007$ & 4,783 & 0.39 & 8.5 & 5 & 11 \\
\hline 2007 & $5 / 19 / 2007$ & 10,074 & 0.43 & 8.0 & 3 & 13 \\
\hline 2007 & $5 / 20 / 2007$ & 4,149 & 0.42 & 6.0 & 2 & 0 \\
\hline 2007 & $5 / 21 / 2007$ & 3,429 & 0.42 & 7.0 & 3 & 13 \\
\hline 2007 & $5 / 22 / 2007$ & 2,959 & 0.44 & 7.0 & 2 & 18 \\
\hline 2007 & $5 / 23 / 2007$ & 2,684 & 0.45 & 6.0 & & \\
\hline 2007 & $5 / 24 / 2007$ & 1,102 & 0.45 & 8.5 & 7 & 15 \\
\hline
\end{tabular}




\begin{tabular}{|c|c|c|c|c|c|c|}
\hline Year & Date & $\begin{array}{l}\text { Chum } \\
\text { Catch }\end{array}$ & $\begin{array}{c}\text { Max Water Stage } \\
\text { (meters) }\end{array}$ & $\begin{array}{c}\text { Max Water Temp } \\
\left({ }^{\circ} \mathrm{C}\right)\end{array}$ & $\begin{array}{c}\text { Min Air Temp } \\
\left({ }^{\circ} \mathrm{C}\right)\end{array}$ & $\begin{array}{c}\text { Max Air Temp } \\
\left({ }^{\circ} \mathrm{C}\right)\end{array}$ \\
\hline 2007 & $5 / 25 / 2007$ & 5,088 & 0.52 & 9.5 & 7 & 0 \\
\hline 2007 & $5 / 26 / 2007$ & 8,636 & 0.59 & 8.0 & 7 & 19 \\
\hline 2007 & $5 / 27 / 2007$ & 4,857 & 0.66 & 9.5 & 7 & 15 \\
\hline 2007 & $5 / 28 / 2007$ & 4,612 & 0.70 & 9.5 & 3 & 16 \\
\hline 2007 & $5 / 29 / 2007$ & 1,294 & 0.70 & & 1 & 16 \\
\hline 2007 & $5 / 30 / 2007$ & 574 & 0.68 & 7.0 & 2 & 15 \\
\hline 2007 & $5 / 31 / 2007$ & 211 & 0.60 & 10.0 & 6 & 16 \\
\hline 2008 & $4 / 29 / 2008$ & & 0.60 & & -12 & 2 \\
\hline 2008 & 4/30/2008 & & 0.28 & 1.0 & 0 & 2 \\
\hline 2008 & $5 / 1 / 2008$ & 1 & 0.26 & 0.5 & -8 & 1 \\
\hline 2008 & $5 / 2 / 2008$ & 1 & 0.25 & 1.0 & -7 & 3 \\
\hline 2008 & $5 / 3 / 2008$ & 35 & 0.23 & 2.0 & -2 & 10 \\
\hline 2008 & $5 / 4 / 2008$ & 224 & 0.27 & 3.0 & 0 & 13 \\
\hline 2008 & $5 / 5 / 2008$ & 238 & 0.37 & 2.0 & -2 & 13 \\
\hline 2008 & $5 / 6 / 2008$ & 525 & 0.47 & 3.0 & -4 & 12 \\
\hline 2008 & $5 / 7 / 2008$ & 832 & 0.62 & 3.0 & 0 & 11 \\
\hline 2008 & $5 / 8 / 2008$ & 858 & 0.68 & 3.5 & 3 & 11 \\
\hline 2008 & $5 / 9 / 2008$ & 1,069 & 0.67 & 4.0 & 3 & 11 \\
\hline 2008 & $5 / 10 / 2008$ & 1,080 & 0.63 & 5.0 & 3 & 11 \\
\hline 2008 & $5 / 11 / 2008$ & 1,362 & 0.58 & 3.5 & 2 & 9 \\
\hline 2008 & $5 / 12 / 2008$ & 1,722 & 0.58 & 5.5 & 2 & 13 \\
\hline 2008 & $5 / 13 / 2008$ & 1,690 & 0.62 & 5.0 & 1 & 11 \\
\hline 2008 & $5 / 14 / 2008$ & 1,746 & 0.59 & 5.5 & -1 & 12 \\
\hline 2008 & $5 / 15 / 2008$ & 1,388 & 0.54 & 7.0 & 1 & 14 \\
\hline 2008 & $5 / 16 / 2008$ & 1,624 & 0.52 & 7.0 & 1 & 13 \\
\hline 2008 & $5 / 17 / 2008$ & 2,021 & 0.51 & 7.0 & -2 & 13 \\
\hline 2008 & $5 / 18 / 2008$ & 1,037 & 0.49 & 6.5 & -2 & 13 \\
\hline 2008 & 5/19/2008 & 1,176 & 0.47 & 7.0 & 3 & 9 \\
\hline 2008 & $5 / 20 / 2008$ & 1,485 & 0.46 & 7.5 & -4 & 13 \\
\hline 2008 & $5 / 21 / 2008$ & 1,006 & 0.44 & 9.0 & 0 & 16 \\
\hline 2008 & $5 / 22 / 2008$ & 733 & 0.45 & 8.5 & 2 & 16 \\
\hline 2008 & $5 / 23 / 2008$ & 1,333 & 0.45 & 7.5 & 4 & 13 \\
\hline 2008 & $5 / 24 / 2008$ & 1,270 & 0.46 & 7.0 & 2 & 13 \\
\hline 2008 & $5 / 25 / 2008$ & 1,133 & 0.45 & 6.0 & 3 & 9 \\
\hline 2008 & $5 / 26 / 2008$ & 1,164 & 0.43 & 6.0 & 0 & 9 \\
\hline
\end{tabular}




\begin{tabular}{|c|c|c|c|c|c|c|}
\hline Year & Date & $\begin{array}{l}\text { Chum } \\
\text { Catch }\end{array}$ & $\begin{array}{c}\text { Max Water Stage } \\
\text { (meters) }\end{array}$ & $\begin{array}{c}\text { Max Water Temp } \\
\left({ }^{\circ} \mathrm{C}\right)\end{array}$ & $\begin{array}{c}\text { Min Air Temp } \\
\left({ }^{\circ} \mathrm{C}\right)\end{array}$ & $\begin{array}{c}\text { Max Air Temp } \\
\left({ }^{\circ} \mathrm{C}\right)\end{array}$ \\
\hline 2008 & $5 / 27 / 2008$ & 751 & 0.43 & 6.0 & 0 & 9 \\
\hline 2008 & $5 / 28 / 2008$ & 517 & 0.41 & 6.0 & 3 & 10 \\
\hline 2008 & $5 / 29 / 2008$ & 443 & 0.41 & 8.0 & 4 & 15 \\
\hline 2008 & $5 / 30 / 2008$ & 350 & 0.43 & 10.0 & 3 & 20 \\
\hline 2008 & $5 / 31 / 2008$ & 497 & 0.45 & 12.0 & 4 & 19 \\
\hline 2008 & $6 / 1 / 2008$ & 867 & 0.50 & 10.0 & 4 & 18 \\
\hline 2008 & $6 / 2 / 2008$ & 2,640 & 0.54 & 9.5 & 4 & 17 \\
\hline 2008 & $6 / 3 / 2008$ & 2,567 & 0.56 & 9.0 & 6 & 15 \\
\hline 2008 & $6 / 4 / 2008$ & 2,278 & 0.58 & 8.0 & 6 & 11 \\
\hline 2008 & $6 / 5 / 2008$ & 1,279 & 0.60 & 9.5 & 4 & 17 \\
\hline 2008 & 6/6/2008 & 726 & 0.60 & 8.0 & 1 & 10 \\
\hline 2008 & $6 / 7 / 2008$ & 508 & 0.60 & 9.0 & 0 & 8 \\
\hline 2008 & 6/8/2008 & 331 & 0.60 & 8.0 & 1 & 10 \\
\hline 2008 & 6/9/2008 & 330 & 0.61 & 9.0 & 2 & 13 \\
\hline 2008 & 6/10/2008 & 210 & 0.59 & 8.5 & 1 & 14 \\
\hline 2008 & $6 / 11 / 2008$ & 121 & 0.56 & 9.0 & 1 & 13 \\
\hline 2008 & $6 / 12 / 2008$ & 113 & 0.54 & 8.0 & 2 & 14 \\
\hline 2008 & $6 / 13 / 2008$ & 240 & 0.56 & 11.0 & 1 & 21 \\
\hline 2008 & $6 / 14 / 2008$ & 181 & 0.59 & 13.0 & 7 & 21 \\
\hline 2008 & $6 / 15 / 2008$ & 1,080 & 0.63 & 10.0 & 7 & 13 \\
\hline 2008 & $6 / 16 / 2008$ & 601 & 0.73 & 9.0 & 7 & 17 \\
\hline 2008 & $6 / 17 / 2008$ & 477 & 0.75 & 9.5 & 4 & \\
\hline 2008 & $6 / 18 / 2008$ & 119 & & & & \\
\hline
\end{tabular}


Publishing support provided by the U.S. Geological Survey Publishing Network, Tacoma Publishing Service Center

For more information concerning the research in this report, contact the Director, Alaska Science Center

U.S. Geological Survey

4210 University Dr.

Anchorage, Alaska 99508-4650

http://alaska.usgs.gov 


\section{$\mathbb{1}$ 劳}

号

믐

咅

흘.

을

言

응

恼.

응

甯

言

올

홀

旅

言

ธิธัฒ

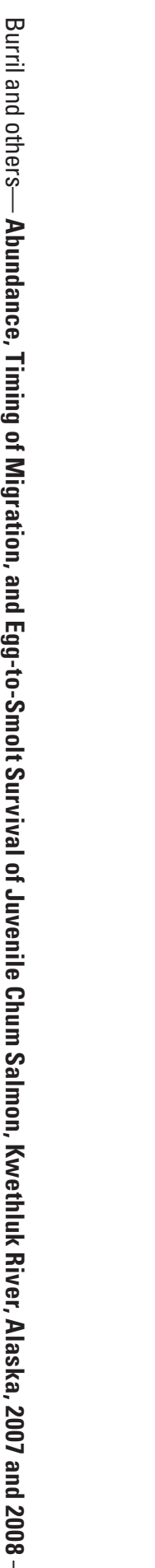

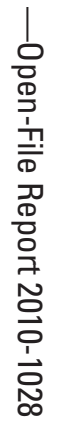

